UNIVERSIDADE DE BRASÍLIA - UnB

INSTITUTO DE CIÊNCIAS HUMANAS - IH

DEPARTAMENTO DE SERVIÇO SOCIAL - SER

\title{
O PARECER SOCIAL COMO INSTRUMENTO DE PODER DO ASSISTENTE SOCIAL NO ÂMBITO DO TRIBUNAL DE JUSTIÇA DO DISTRITO FEDERAL E TERRITÓRIOS.
}

Autora: Sulamita Avelina Soares

Monografia apresentada ao Curso de Serviço Social da Universidade de Brasília - UnB, em cumprimento à exigência para a obtenção do grau de Assistente Social, sob a orientação do professor Msc. Marcos Francisco de Sousa.

Brasília, junho de 2007. 
A

Maria de Fátima e José Maria, meus dedicados e compreensivos pais,

ao Danielson meu irmão e grande incentivador aos meus estudos ao Tércio por todo companheirismo, confiança e amor. 


\section{AGRADECIMENTOS}

A meu orientador, o assistente social Marcos Francisco de Sousa pelo apoio, paciência, orientação e por acreditar na minha proposta de estudo, sendo possível desenvolver este trabalho.

A Ana Lúcia Carneiro profissional marcante na formação profissional, exemplo de profissional atuante, dedicada e compromissada com os princípios éticos da profissão.

Aos meus grandes amigos, por todas as alegrias vividas e por toda compreensão nos dias de fúria.

A todos os professores do curso de graduação, pela valiosa contribuição nos meus estudos e formação acadêmico-profissional.

Às assistentes sociais entrevistadas por partilharem sua compreensão àcerca do tema.

$\mathrm{E}$ aos amigos da CEPEMA, pelas boas lembranças de um trabalho no qual acredito e deposito todas as melhores expectativas.

A todos a minha gratidão. 


\section{RESUMO}

SOARES, Sulamita Avelina. O parecer social como instrumento de poder do assistente social no âmbito do Tribunal de Justiça do Distrito Federal e Territórios 2007. 69f. Trabalho de conclusão de graduação do curso de Serviço Social - Universidade de Brasília, Brasília: 2007.

Este trabalho tem como objeto de estudo e análise o parecer social como instrumento de poder dos assistentes sociais da Central de Penas e Medidas Alternativas do Tribunal de Justiça do Distrito Federal e Territórios. Os objetivos que se buscou alcançar nesta pesquisa foram o aprofundamento do estudo das implicações do poder institucional na atuação do Serviço Social no Judiciário, a partir das dimensões teórico-metodológicas, ético-políticas e técnicooperativas. Para a consecução de tais objetivos, realizou-se: (i) uma pesquisa exploratória com a utilização de coleta de dados para fundamentar teoricamente o estudo, destacando a construção do conhecimento científico e o desenvolvimento histórico do Serviço Social, bem como as particularidades dos instrumentos e técnicas do trabalho do assistente social; (ii) uma pesquisa de campo, desenvolvida a partir de entrevistas semi-estruturada, no qual foram escolhidos 05 assistentes sociais inseridos em uma equipe multidisciplinar, que realizam pareceres sociais em sua rotina de trabalho. A análise dos dados permitiu concluir que a prática e a teoria juntas resultam na produção de pareceres e relatórios e estes refletem o domínio de conhecimento do profissional, sendo considerado como instrumento de poder capaz de ampliar e defender os direitos de seus usuários.

Palavras-chave: Serviço Social. Judiciário. Parecer Social. 


\section{SUMÁRIO}

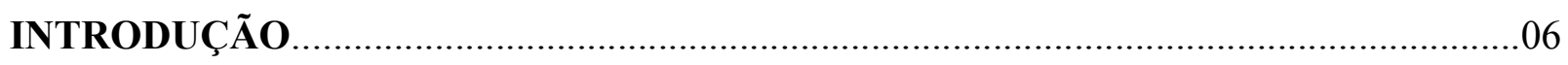

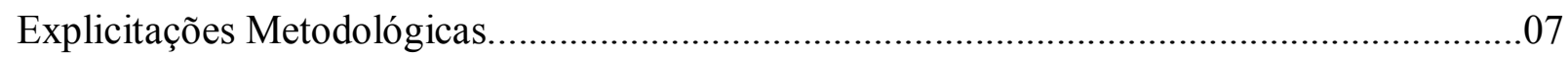

CAPÍTULO I

1. CIÊNCIA E CIENTIFICIDADE: CONSIDERAÇÕES SOBRE SABER, VERDADE E

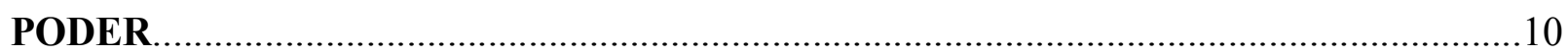

\section{CAPÍTULO II}

2. SABER E VERDADE NO SERVIÇO SOCIAL ...........................................................20

2.1 Sobre a instrumentalidade no Serviço Social. .......................................................35

\section{CAPÍTULO III}

3. O PARECER SOCIAL COMO INSTRUMENTO DE PODER DO ASSISTENTE

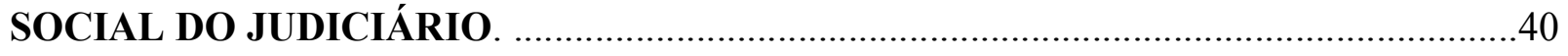

3.1. A CEPEMA como lócus de pesquisa.............................................................40

3.2. Saber e verdade em Serviço Social: ciência ou disciplina?.................................46

3.3 Parecer, Laudo e/ou Relatório Social...............................................................50

3.4 Os Relatórios como fonte de poder.................................................................57

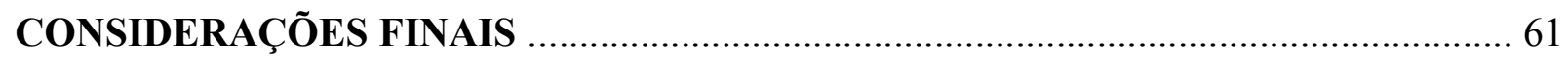

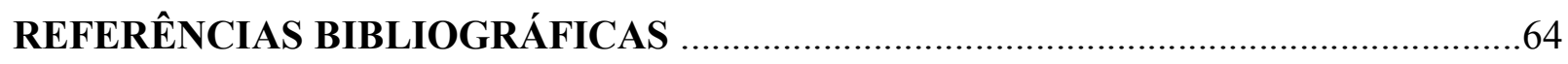

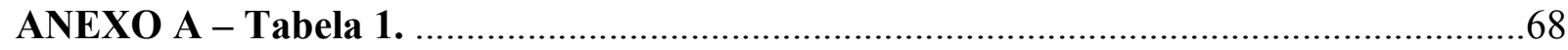

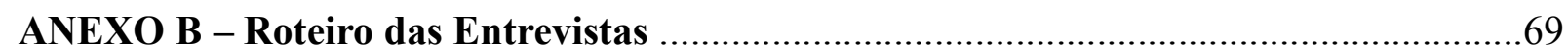




\section{INTRODUÇÃO}

O presente trabalho corresponde à monografia apresentada à graduação do Departamento de Serviço Social da Universidade de Brasília (UnB) e surgiu a partir da experiência de estágio na Seção Psicossocial da Central de Coordenação da Execução de Penas e Medidas Alternativas (CEPEMA) no Tribunal de Justiça do Distrito Federal e Territórios (TJDFT) no período de março de 2005 a maio de 2006.

Neste sentido, este estudo propôs estudar as implicações do poder institucional na atuação do Serviço Social no Judiciário, a partir das dimensões teórico-metodológicas, técnicooperativas e ético-políticas, considerando como elemento central a análise de um instrumento na qual se materializa o poder e saber do assistente social: o parecer social.

Partiu-se do entendimento de que o parecer social não se restringe a um mero artifício de trabalho do assistente social, mas como um instrumento de viabilização de direitos, um meio de realização do compromisso com os usuários, em vista da equidade, igualdade, a justiça social e cidadania (CFESS, 2003: 47). Tomou-se como objeto de estudo o parecer social como instrumento de poder dos assistentes sociais da Central de Coordenação da Execução das Penas e Medidas Alternativas - CEPEMA do Tribunal de Justiça do Distrito Federal e Territórios.

O interesse pelo tema se deu, primeiramente, no momento em que se verificou não existir um estudo sobre o Parecer Social no âmbito do Serviço Social no TJDFT, sendo notável a carência bibliográfica sobre a matéria, com falta de teorização e reflexão da prática do assistente social no âmbito do judiciário.

Outro motivo pelo qual nasceu este interesse foi pelo contato direto com profissionais de outras áreas do conhecimento humano-social, além do Serviço Social, tais como: Direito, Psicologia e Pedagogia, que possuem distintas atuações e intervenções diante das demandas jurisdicionais e realizam um trabalho multidisciplinar no assessoramento às decisões dos Magistrados, inserindo o assistente social em complexas relações de saberes e poderes.

O estudo das relações de poder pode ser analisado por diferentes formas e enfoques. Contudo, o enfoque desta pesquisa correlaciona o poder com o saber, pois aquele constrói uma

prática discursiva, uma "verdade" que legitima as práticas sociais, pois o poder dialoga 
diretamente com o saber, e como bem lembra Faleiros (2001: 10) "saber e poder são meio e fim que se articulam em cada conjuntura: saber para poder e poder para saber”.

Esta pesquisa pretende contribuir para uma discussão mais aprofundada sobre o Parecer Social como instrumento de poder do assistente social no contexto do poder Judiciário, a partir da instrumentação técnica do profissional de Serviço Social, ao pretender discutir os limites impostos para o assistente social dentro da organização judiciária, bem como seus instrumentos e técnicas utilizados para realização de seu trabalho.

A pertinência e atualidade desta pesquisa justificam-se, uma vez que há pouca produção de conhecimento a respeito do tema central - parecer social - sendo este um dos instrumentos mais utilizados pelos assistentes sociais no Judiciário.

\section{Explicitações Metodológicas}

A pesquisa apoiou-se no método de análise qualitativo dos dados, por ser uma pesquisa social que tem como objeto estudar o parecer social como instrumento de poder elaborado pelo assistente social na CEPEMA.

Para isso, as categorias analíticas-chave eleitas para estudo foram: Serviço Social, Judiciário e Parecer Social.

Trata-se, portanto, de pesquisa exploratória que requer a utilização de instrumentos de coleta de dados como a pesquisa bibliográfica, para fundamentar teoricamente o estudo e a pesquisa de campo, desenvolvida a partir das entrevistas semi-estruturada, sendo necessário estabelecer um roteiro direcionado para o núcleo temático do estudo e, conseqüentemente, para o objeto da pesquisa. Observa-se que foram escolhidos 05 (cinco) assistentes sociais (analistas)

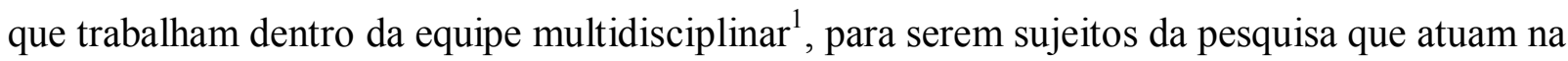
psicossocial da CEPEMA do Tribunal de Justiça do Distrito Federal e Territórios.

E, para atingir o objetivo desta pesquisa foram abordados os seguintes procedimentos metodológicos, divididos em duas fases:

\footnotetext{
1 A composição atual da equipe é de 06 Assistentes Sociais, 02 pedagogos, 02 psicólogos 01 técnica e 05 estagiários, sendo que 02 são do Serviço Social, 01 da psicologia e 02 de administração.
} 


\section{$1^{\text {a }}$ Fase: exposição teórica}

Esta fase inicial foi composta pela explicitação teórica deste estudo, primando pela investigação e análise das três categorias principais, destacando a formação do conhecimento científico ou não do Serviço Social, discorrendo sobre as diferentes perspectivas dos principais autores que tratam sobre o assunto, bem como as particularidades dos instrumentos e técnicas de seu trabalho. Posteriormente, tratou-se propriamente do instrumental técnico-operativo como instrumento de poder do assistente social.

\section{$2^{\text {a }}$ Fase: pesquisa de campo}

Com o fito de verificar como se dá a relação entre o poder e o saber profissional por meio dos pareceres sociais, realizou-se entrevistas semi-estruturadas com as assistentes sociais da CEPEMA. Foram realizadas 05 entrevistas com os profissionais de Serviço Social. O critério para a seleção das entrevistadas foi trabalhar como analista dentro da área de Serviço Social realizando pareceres sociais em sua rotina de trabalho.

A partir desta etapa passou-se para a transcrição e análise das entrevistas correlacionando-as com o estudo teórico.

Os resultados da pesquisa foram estruturados em três capítulos com enfoques distintos e complementares.

No primeiro capítulo, discorreu-se sobre o conceito complexo de ciência e conhecimento que tem como finalidade a construção de saberes e verdades instituídas em relações de poder e, a partir desta, a busca pela verdade que prepondera sobre as outras formas do conhecimento e ganha com isto status de poder. Sendo assim, o primeiro capítulo procura definir cientificidade, método, técnica, ciência, sua construção histórica, críticas, perspectivas e principais vertentes e classificações.

No segundo capítulo, trata-se da discussão de cientificidade e profissionalidade do Serviço Social, partindo da evolução histórica da profissão, passando pelas suas principais correntes de pensamento (positivismo, funcionalismo e marxista), e expondo os posicionamentos divergentes de autores que defendem ou não a cientificidade do Serviço Social. 
No terceiro capítulo, apresentou-se o lócus da pesquisa, com ênfase na análise das entrevistas correlacionando-as com o saber e verdade em Serviço Social, com o estudo de sua instrumentalidade e dos principais instrumentais, destacando-se o parecer e o relatório social.

Assim sendo, conclui-se que o parecer social além de ser documento e meio de comunicação utilizado pelos assistentes sociais nos tribunais de justiça é considerado também como um instrumento de poder capaz de ampliar e defender os direitos de seus usuários.

Neste sentido, a pesquisa finaliza com o intento de ter contribuído um pouco mais com a discussão sobre a questão do saber, do poder, e da instrumentalidade do Serviço Social. Pretendeu-se também dar maior visibilidade a um tema pouco discutido na formação acadêmica e por existirem pesquisas escassas que tratem sobre o assunto. Espera-se, portanto, que esta pesquisa embrionária sirva de incentivo para outras pesquisas futuras sobre a temática do Parecer Social como instrumento de poder. 


\section{CAPÍTULO I}

\subsection{Ciência e Cientificidade: considerações sobre saber, verdade e poder.}

A busca da humanidade pelo conhecimento é, e será sempre, motivo de muita discussão e discórdia de opiniões. A partir do momento em que o homem procura compreender e construir sua própria concepção de verdade sobre a realidade deixa de lado as verdades transcendentais, supra-terrenas e acríticas que não conseguem responder a diversos questionamentos que lhes foram surgindo ao longo do tempo.

Ao longo dos tempos a ciência veio adquirindo um grande status de reconhecimento por estudar e buscar a verdade, ou seja, por ser atribuída a característica de instrumento para a descoberta da verdade, garantindo a ela uma hegemonia sobre outras formas de conhecimento, isto é, um status de conhecimento quase indiscutível. Isto refletiu diretamente no poder depositado na ciência.

Hoje a ciência constitui a forma dominante de "construção de verdades" sobre a realidade, apesar de existirem outras preocupações humanas (políticas, religiosas, técnicas, ideológicas) que, também, procuram atingir estas verdades. Contudo, prevalece a idéia de que é a ciência que consegue organizar essas "verdades" em sistemas, conjuntos e afirmações relacionadas que se tornam, muitas vezes, incontestáveis.

Para Minayo, na sociedade ocidental, a ciência é a forma hegemônica de construção da realidade, sendo considerada como um novo mito, por sua pretensão de ser o único promotor e critério de verdade (1993: 10).

Sendo assim, que não há como esconder o reconhecimento da ciência, basta olhar para a história e ver quantas vezes o conhecimento cientifico decidiu os rumos da história: as guerras mundiais, tratamento e cura de doenças, estudo da astronomia, da genética, das classes sociais, enfim, incalculáveis as mudanças provindas da ciência. Contudo, o poder que se destaca nesta pesquisa é o que está implicitamente instituído na palavra ciência. 
Hoje, o problema central da ciência é a sua definição ${ }^{2}$ quanto ao que é, ou não, científico. Sendo assim, a ciência tem como objetivo clássico explicar e compreender a realidade da maior e melhor maneira possível.

Neste contexto, o primeiro ponto que requer uma atenção maior na produção do conhecimento científico é o método. Sabe-se que o cientista tem como objetivo fundamental chegar à veracidade dos fatos. Neste ponto, não se distingue de outras formas de conhecimento que possuem o mesmo objetivo, contudo o que torna o conhecimento científico distinto dos demais é que possui como característica fundamental sua verificabilidade (GIL, 1995: 27).

Para que um conhecimento possa ser considerado científico, torna-se necessário identificar as operações mentais e técnicas que possibilitam a sua verificação. Em outras palavras, determinar o método que possibilitou chegar a este conhecimento.

Segundo Minayo (1993: 16), metodologia é o caminho do pensamento juntamente com a prática exercida na abordagem da realidade. Neste sentido, método é o meio, é o caminho para se chegar a determinado fim. Assim, o método científico é o conjunto de procedimentos intelectuais e técnicos adotados para se atingir determinado conhecimento. Há de se destacar principalmente a articulação entre os conteúdos trabalhados, pois serão a partir destes, somados à determinadas técnicas, que se possibilitará a construção do conhecimento.

Gil (1995: 27) destaca que no passado muitos pensadores manifestaram suas aspirações em definir um método universal, único, aplicável a todos os ramos do conhecimento. Conjugando com esta afirmação, Chauí (1998: 252) coloca que os gregos trabalhavam a partir desta concepção do todo, ou seja, preconizava o conhecimento racional como uma unidade sistemática de axiomas, postulados e definições que determinam a natureza e as propriedades de seu objeto científico que era a representação intelectual universal das coisas correspondente à própria realidade. No início da ciência, o que se propunha era uma visão unívoca sobre a realidade, porém a realidade não é única, nem a forma de percebê-la e construí-la.

Já a ciência moderna parte para a construção de métodos diferentes, adaptáveis aos objetos, teorias e técnicas distintas, ou seja, para cada área do conhecimento existe um método específico. Daí surgir distintas regras metodológicas que nos fornecem critérios para a avaliação dos procedimentos científicos. Surge automaticamente, também, uma diversidade de métodos determinados pelo tipo de objeto a investigar e pela classe de proposições a descobrir,

\footnotetext{
${ }^{2}$ Embora diversos filósofos da ciência procurem conceituar, definir e classificar a ciência, esta é fruto de um processo histórico mais complexo que não cabe em uma formulação reduzida, limitada e excludente.
} 
diferentemente do método antigo que tentava explicar por um só método acontecimentos na natureza, astronomia, na realidade como um todo. Hoje, pode-se afirmar, por exemplo, que dentro das ciências exatas a matemática não tem o mesmo método da física e que esta não tem o mesmo método da astronomia, cada uma desenvolveu seus métodos próprios. E, com relação às ciências sociais, pode-se mesmo dizer que dispõem de uma grande variedade de métodos, como os gerais, que proporcionam a base lógica para investigação: hipotético-dedutivo, o dialético, e o fenomenológico ${ }^{3}$.

Como bem colocado por Minayo (1993: 16), metodologia é o caminho do pensamento juntamente com a prática exercida na abordagem da realidade. Ou seja, é o método com a técnica. Enquanto técnica, a metodologia deve dispor de um instrumental claro, coerente, elaborado, capaz de encaminhar os impasses teóricos para o desafio da prática.

Ao fazer referência às ciências naturais, o que procura-se destacar é a sua influência sobre toda a forma de se pensar e fazer ciência (no sentido moderno do termo), pois, juntamente com as ciências matemáticas, foram as primeiras a trabalharem o conceito de ciência, tornando-se conseqüentemente referência para as correntes posteriores, delineando os primeiros traços de poder de um saber sobre outros saberes.

Importante ressaltar que em virtude da multiplicidade de objetos considerados pela ciência, desenvolveram-se diversas correntes científicas, sendo necessário discorrer sobre sua classificação genérica para melhor visualizar o quanto o tema é controverso, já que não existe, e nem deve existir, uma classificação determinada que compreenda todas as concepções de ciência, pois, ao classificá-la rigorosamente, estar-se-ia correndo o risco de delimitar, ou até mesmo restringir, um conceito tão complexo como o de ciência.

Chaui (1998: 260) subdivide a ciência em quatro campos:

\footnotetext{
${ }^{3} \mathrm{O}$ método dedutivo, de acordo com a acepção clássica, é o que parte do geral para o particular. O raciocínio dedutivo parte de princípios considerados como verdadeiros para chegar a conclusões de maneira puramente formal (GIL, 1995: 28).

O método dialético é constituído de alguns princípios: i) Princípio da unidade e da luta dos contrários: todos os objetos e fenômenos apresentam aspectos contraditórios que são organicamente unidos e constituem a indissolúvel unidade dos opostos; ii) Princípio da transformação das mudanças quantitativas em qualitativas: as mudanças quantitativas graduais geram mudanças qualitativas; iii) Princípio da negação da negação: o desenvolvimento processa-se em espiral, com a repetição em estágios superiores de certos aspectos e traços dos estágios inferiores. (Ibid., p. 28).

O método fenomenológico consiste em explicar o que é dado e em esclarecer este dado. Não explica mediante leis nem deduz a partir de princípios, mas considera imediatamente o que está presente à consciência, o objeto. (GIL, Ibid., p. 28).
} 
a. ciências matemáticas ou lógico matemáticas (aritmética, geometria, álgebra trigonometria, lógica, física pura, astronomia pura etc.). Têm como objeto principal os números, que são trabalhados universalmente de forma singular e perfeita.

b. ciências naturais (física, química, biologia, geologia, astronomia, geografia física e paleontologia). Têm como objeto estudar duas ordens de fenômenos: os físicos e os vitais. Distinguem-se por desfrutar de um grau de alta certeza, desfrutando posição privilegiada com relação aos demais tipos de conhecimento (o do homem comum, por exemplo).

c. ciências humanas ou sociais (psicologia, sociologia, antropologia, geografia humana, economia, lingüística, psicanálise, arqueologia e história). A situação de tais ciências é especial, por não ser passível de quantificação, por ter uma participação subjetiva do investigador, por seu objeto (o ser humano) ser bastante recente e porque surgiram depois que as ciências matemáticas e naturais estavam constituídas e que já haviam definido a idéia de cientificidade, de métodos e técnicas, no momento em que prevalecia a concepção empirista e determinista de ciência ${ }^{4}$.

d. ciências aplicadas (todas as ciências que conduzem a invenção de tecnologias para intervir na Natureza, na vida humana e nas sociedades, como por exemplo, direito, engenharia, medicina, arquitetura, informática, etc).

Outro autor que destaca uma classificação geral é Gil (1995: 22). Para este autor a ciência pode ser dividida em duas grandes categorias: formais e empíricas (ou reais). As primeiras, chamadas lógico-matemáticas, tratam de entidades ideais e de suas relações. Como nelas não se pode demonstrar tudo, parte-se de princípios que devem ser aceitos sem demonstração (axiomas). Já as ciências reais ou empíricas lidam com fatos e processos que podem ser classificadas em dois grupos: as naturais e as humanas ou sociais.

\footnotetext{
${ }^{4}$ Empirismo é um método filosófico baseado na idéia de que a única forma válida de conhecimento é aquela obtida através do emprego dos sentidos. Concepção que tem como enunciado o empírico que descreve observações ou pesquisas baseadas em observações concretas. De acordo com este ponto de vista, se alguma coisa não pode ser observada, então de nada adianta tentar explicar fenômenos naturais ou de qualquer outro tipo (JOHNSON, 1997: 83).

Já o determinismo é um modo de pensar que supõe que tudo é, de modo previsível, causado por alguma coisa. Mais especificamente descreve qualquer teoria que explique o mundo em termos de alguns fatores estreitamente definidos, com exclusão de todos os demais (Ibid., p. 71).
} 
Este é um ponto de grande importância por ser uma tentativa de demarcação da ciência, pois como dito no início, estabelecer critérios definidores para ciência é um problema, pois, ao defini-los poderia estar se restringindo e limitando seu estudo em meio a estes critérios. Contudo, a divisão que o autor coloca é a mais aceita no meio acadêmico por dividir a ciência em ciências formais, ou seja, aquela que tem como objeto os processos mentais de trabalho (idéias), abstrações realizadas através de uma construção mental e que não provém diretamente do mundo real, não passando de um pensamento, diferentemente da complexidade do real.

Já as ciências reais têm como objeto os fatos, os fenômenos, as situações reais, ou seja, tem existência independente da nossa mente, e suas características são percebidas pelos sentidos. Nesse caso não são meras abstrações objetivas, mas fatos que acontecem independentemente do homem percebê-las ou não. Dessa maneira, é a partir do momento em que o homem percebe estes fatos e tenta estudá-los que se cria uma outra forma de fazer ciência, não mais abstrata e sim real. E como exposto pelo autor, as ciências reais dividem-se em duas grandes áreas: ciências naturais e ciências humanas, onde cada uma possui métodos, técnicas e estilos de pesquisas distintas, todavia ambas possuem em comum a característica do contato com o real, o concreto.

As ciências da natureza desde seu princípio foram caracterizadas por seguir o ordenamento das leis naturais e racionais. Chaui (1998: 264) destaca que nestas ciências não existe o acaso, pois este é um acontecimento muito singular que não afeta as leis universais da natureza. Segundo a autora, as ciências da natureza estudam os fatos observáveis que podem ser submetidos aos procedimentos de experimentação, estabelecendo leis universais aos fatos investigados, e que buscam constâncias, regularidades, freqüências e invariantes dos fenômenos, isto é, seus modos de funcionamento e de relacionamento.

O traço que marca a diferença entre o cientista e o não cientista é o processo de obtenção, justificação e transmissão do conhecimento, ou seja, seu método de obtenção e sua técnica de desenvolvimento destas informações até se tornarem leis universais. $\mathrm{Na}$ visão das ciências da natureza, o cientista possui pressuposições centrais que são a observação pura, neutra, objetiva e indutiva, onde se critica o senso comum. Dentre as principais características do que é ou não científico nas ciências da natureza podemos analisar com maior profundidade alguns ponto centrais:

i) tendência de encaixar todos os fatos dentro de leis universais, excluindo de imediato tudo que se pode considerar como senso comum, saber este visto como um conjunto de informações não sistematizadas apreendido através de processos formais e informais 
conjugados com uma valoração. Para Demo (1985: 14) as ciências naturais excluem este tipo de conhecimento por ser pautado como acrítico, imediatista, que não enxerga a complexidade da realidade e que acredita na superficialidade do fenômeno.

ii) tendência de supor uma objetividade conjugada com a neutralidade, na qual o cientista se desvincula da identidade de sujeito, de todas as ideologias e subjetividade, para estudar somente sob a perspectiva do objeto em si. Demo (1985: 17) coloca o critério da objetividade como utópico, já que o autor rejeita a neutralidade e a objetividade científica, como requisitos para se fazer ciência. Não há que se falar em objetividade, mas sim em objetivação, ou seja, é somente um esforço de controlar a subjetividade dentro dos limites da suposta objetividade, já que não se pode realizá-lo plenamente.

iii) tendência de elaborar conhecimento a partir dos fatos reais ou dos fenômenos da natureza sendo, portanto, suscetível de modificação, à medida que o nosso conhecimento da realidade vai se aperfeiçoando.

Lungarzo (1989:36) trata um dos pontos mais característicos das ciências da natureza que é a tentativa de explicar a ocorrência de fatos passados e predizer a ocorrência dos fatos futuros através das chamadas teorias universais. Estas teorias tencionam atingir certa confiabilidade e respeitabilidade sempre aspirando a verdade, que prevalecerá sobre todas as outras formas de conhecimento. Demonstrando mais uma vez o poder que a ciência natural adquiriu ao longo dos tempos, com status de até predizer verdades futuras, o que a torna “incontestável” perante outras formas de conhecimento.

Contudo, estudar propriedades, fatos previsíveis e mecanismos da natureza não compreendia o estudo dos fenômenos sociais, das atividades dos homens, da produção de cultura, por serem estes mais complexos e bem mais difíceis de se predizer. Surge daí a necessidade de estudar o homem e as suas relações de forma mais aprofundada, dar atenção a um objeto não passivo, um ser inteligente que tem uma capacidade superior de transformar o mundo. E para este conhecimento novo ${ }^{5}$ cria-se um marco na história da ciência, pois surge a importante categoria: as ciências humanas ou sociais.

\footnotetext{
5 Segundo Lungarzo, (1989: 37) ainda que a preocupação pelo homem fosse muito antiga, até o século XVIII era pouco o que se estudava de um ponto de vista científico. Segundo o autor, foi somente após a Primeira Guerra Mundial que começam a aparecer as disciplinas que estudam o homem com as características que hoje reconhecemos de ciência. Disciplinas como sociologia, psicologia, antropologia, história, dentre outras, ganharam crédito acadêmico e passam a ser lecionadas e pesquisadas nas universidades.
} 
As ciências humanas (ou sociais) passam a tomar para si como objeto de estudo e conhecimento o homem em suas relações sociais. Da mesma forma, buscam construir verdades próprias, baseadas, também, em teorias, proposições e métodos próprios.

Segundo Vila Nova (1984: 59) as ciências sociais nascem antes como utopia do que como conhecimento rigoroso, marcada pela concepção de uma ciência útil ao aperfeiçoamento moral e, portanto, político e econômico das relações sociais. Vale destacar a influência que o pensamento positivista teve sobre as ciências sociais. Este pensamento tinha como pressuposto básico a possibilidade de construir conhecimentos sobre a realidade humano-social utilizando os mesmos métodos das ciências naturais: objetividade, neutralidade e leis universais.

Assim, o pensamento positivista fundamentou-se na hipótese de que a sociedade pode ser regida por leis naturais tal como ocorria nas ciências naturais. Estas leis invariáveis e independentes da vontade humana a regulavam, cabendo somente conservá-la para a manutenção da ordem e do equilíbrio da sociedade. Augusto Comte (apud VICENTE 1989: 132), reconhecido como o pai do positivismo, propunha uma física do social pela qual os fenômenos sociais deviam ser submetidos às leis naturais invariáveis à semelhança dos fenômenos físicos, ou seja, o estudo científico da sociedade partindo do homem como ser social, usando métodos, técnicas e procedimentos empregados pela ciência da natureza.

A característica da tradição positivista de só aceitar o observável, os fatos, as coisas, trouxe problemas para as ciências humanas, pois os fenômenos humanos não ocorrem de acordo com uma ordem semelhante à observada no universo físico, o que torna impossível sua previsibilidade. As ciências humanas (ou sociais) lidam com entidades que não são passíveis de quantificação envolvendo os fenômenos sociais uma variedade tão grande de fatores que torna-se impossível a realização de uma pesquisa rígida e experimental (GIL, 1995: 22).

O pensamento positivista é, portanto, uma filosofia determinista que professa os estudos das causas e efeitos de uma sociedade através de teorias naturais e de forma mais equivocada, com caráter universal que ordena todas as relações sociais. Se existe um comportamento destoante este deve ser corrigido para que não influencie os demais. A bandeira fundamental da filosofia positiva foi o progresso e a ordem.

Um dos grandes reflexos do positivismo foi a fragmentação do saber na tentativa de criação de sua própria verdade, tendo como conseqüência a divisão do trabalho em diversas funções e especializações. Para o positivismo, a fragmentação representava uma questão essencial para o próprio progresso científico. É com a fragmentação do saber que surge o especialista e as fronteiras entre as disciplinas se alargaram. É a partir deste destaque para as 
particularizações das funções que inicia-se a política de especialização ${ }^{6}$ nos diversos campos de trabalho.

Sobre a fragmentação do saber Severino expõe que:

"O Positivismo torna-se, portanto, no limiar da contemporaneidade, o maior responsável pela fragmentação do Saber e o maior obstáculo à própria interdisciplinaridade. [...] Marcou profundamente as feições da cultura contemporânea, de modo particular no aspecto epistemológico. Consagrou a proposta das especializações, que, se não chegaram a comprometer o esforço de unificação no âmbito das Ciências Naturais, comprometeu-o, de forma inevitável, no âmbito das Ciências Humanas". (SEVERINO, 1995: 15).

De acordo com o autor, a pluralidade dos caminhos que a ciência tomou, por influência do positivismo, comprometeu substantivamente a sua unidade do saber, criando com isto uma suposta multiplicidade dos aspectos do real. Ou seja, o cientista deixa de ter uma visão do todo para focalizar uma área específica, obtendo com isto múltiplas formas de perceber a realidade e, conseqüentemente, de produzir conhecimentos distintos sobre uma mesma realidade. O exemplo básico é o das ciências médicas que afunilaram seu conhecimento a tal ponto de perder a visão completa do ser humano. O mesmo ocorreu no campo das ciências humanas ou sociais que sofreram esta especialização com reflexos diretos na produção de conhecimento mais especializado como: economia, psicologia, sociologia, antropologia. E somente em tempos posteriores a fragmentação vem sendo revista com o movimento da interdisciplinaridade ${ }^{7}$. Ora, não dá para se fragmentar o saber das Ciências Sociais, pois estas "têm como objeto o homem que é uma unidade e não uma acumulação de várias visões parciais" (SEVERINO, 1995: 19).

Por fim, o positivismo alterou também o campo das profissões que têm como particularidade não só o conhecimento, mas também a intervenção na realidade social e humana, pois ao realizar um trabalho prático, deve-se levar em consideração todos os seus pontos de vista e condicionantes de determinada realidade. Por isto mesmo estas profissões precisam complementar sua intervenção com conhecimentos empíricos e práticos de diversas

\footnotetext{
${ }^{6}$ Há uma tendência na ciência moderna que afirma, "o conhecimento avança pela especialização". O conhecimento pode ser tanto mais rigoroso quanto mais estrito é o objeto sobre que incide. O seu rigor aumenta na proporção direta em que espartilha o real (SARMENTO, 1994: 235).

7 O movimento da interdisciplinaridade surgiu com a promessa de romper com a epistemologia positivista, visando garantir a construção de um conhecimento globalizante e totalizante rompendo com as fronteiras das diversas disciplinas. Sabe-se contudo, que apesar da preocupação crescente com a interdisciplinaridade, surge a cada dia novas disciplinas permitindo que a especialização caminhe a passos largos. Retratando de forma clara a grande herança que o positivismo trouxe e traz para história do conhecimento.
} 
áreas do conhecimento, para assim, obter subsídios para compreender a realidade de forma integrada. Evitando, tal como afirma Severino (1995: 19), "uma hipertrofia, seja de uma fundamentação unidimensional, seja de uma intervenção puramente técnico-profissional".

Veremos no capítulo seguinte que o Serviço Social também sofreu profunda influência desta corrente filosófica no momento em que passa a buscar a sua especificidade em termos de objeto, teoria e método, no campo das ciências sociais.

As ciências sociais ao perceberem que o método científico das ciências naturais não satisfazia seus objetivos, diante da complexidade das relações humanas, despertaram para a superação deste método, para propor o estudo próprio das ciências humanas. Estudo este que não percebe o objeto (o homem) como um fato dado a priori, mas sim, pelo estudo de um objeto construído capaz de apreender a complexidade da sociedade humana, que não se enquadra em leis rígidas, mas que vai além, isto é, o estudo da realidade humana é um emaranhado de diferentes fatores e efeitos interagindo entre si, simultaneamente. O homem é um ser pensante e afetivo, de forma que suas relações são regidas por uma série de fatores inter e intrapessoais que influenciam na sua capacidade de perceber e transformar a realidade. $\mathrm{O}$ homem não é um objeto "passivo" como o objeto das ciências naturais (as forças, a energia, as células, os planetas, etc). O homem é um ser que está em constante movimento e em interação com todos os tipos de seres, animados e inanimados.

As questões referentes à produção de conhecimento das ciências humanas são extremamente complexas, exigindo soluções e adaptações alternativas a cada caso. Chacur (1983) afirma que as ciências humanas possuem uma situação sui generis, por ter como objeto específico - o homem - referindo à questão de sua instabilidade metodológica. As ciências humanas contemporâneas não definiram sua epistemologia com base nas ciências dedutivas, não contemplaram em sua metodologia o modelo rigoroso das ciências exatas. No entanto, optaram por conduzir sua metodologia crítica com a finalidade de obter um conhecimento rigoroso da realidade social, buscando-se estudar o homem e suas relações sociais.

Confirmando esta perspectiva, Minayo (1993: 14) afirma que as ciências sociais não podem ser reduzidas a uma forma determinada de conhecer, pois pré-contêm diversas maneiras concretas e potenciais de realização. Ao mesmo tempo, seu objeto é histórico, ou seja, significa que as sociedades humanas existem num determinado espaço cuja formação social e configuração são específicas. Portanto, as ciências sociais procuram produzir, com base na historicidade, na subjetividade, no dinamismo e na especificidade de seu objeto (homemhistórico) um conhecimento sobre a realidade social. 
E, finalizando essas reflexões acerca da ciência é necessário destacar a importância da ideologia perante nossa realidade cultural, buscando entender o processo histórico que a produz, assim como suas relações de poder e confronto dentro da sociedade para, se pensar em que nível se dá este processo de conhecimento. Como vimos, ao longo dos tempos a ciência veio adquirindo um grande status de reconhecimento por estudar e buscar a verdade, ou seja, por ser atribuída a característica de instrumento para a construção da verdade, garantindo a ela uma hegemonia sobre outras formas de conhecimento, ou em outras palavras, um status de conhecimento quase indiscutível.

A partir desta colocação surge a seguinte pergunta: como ficam as outras formas de conhecimento (dentre elas o Serviço Social), não caracterizadas dentro do modelo tradicional de ciência? Será que elas estão condenadas à exclusão?

Quando se intitula que determinado saber, é o que detém a verdade, as demais formas de saberes, não elegidas como fonte de verdade, são excluídas, gerando-se assim a resistência destes para com aqueles, ou seja, uma correlação de forças, tanto para se manterem como fonte de verdades (ciências), quanto para serem também reconhecidas com confiança (não-ciências). Neste ponto, surge a hierarquia de poder de um conhecimento sobre o outro de forma que, ao não se conceder a uma disciplina, o status de ciência, acaba-se por coloca-lo em um patamar ordinário de conhecimento.

Por isto, torna-se importante ressaltar que não há como se falar de ciência (latu sensu) de um modo unívoco em todas as épocas, por ter como foco principal o estudo da realidade. $\mathrm{Na}$ verdade, esta não é estática e imutável, mas retrata as necessidades de uma determinada sociedade em uma determinada época. Não há que se falar de ciência como algo padronizado, mesmo que sua metodologia científica esteja restrita a uma determinada comunidade científica que procura eleger como paradigma uma concepção de ciência que melhor se adeque ao seus interesses.

Enfim, importante colocar que tais discussões sobre a definição de ciência e o que seria ou não científico são importantes para se pensar o objeto da presente pesquisa, pois se configura como debate ainda latente sobre a especificidade do Serviço Social, em termos de metodologia própria, condição básica para adquirir o status de ciência. Status este que dentro do paradigma moderno de ciência, pressupõe a definição de um objeto, teoria e metodologia próprios. Ao passo que determinadas profissões mesmo não estando enquadradas nesta base, baseiam-se na compreensão, explicação e intervenção na realidade a partir de critérios de cientificidade. 


\section{CAPÍTULO II}

\section{Saber e verdade no Serviço Social}

Pensar o "Parecer Social" como um dos principais instrumentos de saber/poder do assistente social no judiciário, mais especificamente na CEPEMA, envolve-nos a retomar, mesmo que solitariamente, uma discussão de fundo que, apesar de aparentemente superada entre a intelectualidade da profissão, ainda permanece latente entre os "profissionais da prática": a questão da especificidade da profissão, em termos de objeto, teoria e metodologia próprios, fundamental para se problematizar as particularidades teórico-metodológicas, éticopolíticas e técnico-operativas presentes nos relatórios técnicos dos assistentes sociais da CEPEMA/TJDFT.

Sendo assim, torna-se necessário delimitar uma rota de discussão que revitaliza o debate sobre a especificidade da profissão (e a intrínseca relação entre teoria/prática) no marco da própria polêmica sobre a profissionalidade do Serviço Social, ou seja, a sua constituição como "ciência" e como "profissão".

Dado o seu caráter interventivo, o Serviço Social foi caracterizado, em sua origem, como profissão eminentemente religiosa, com características predominantes da benemerência, caridade e filantropia. Foi no decorrer do seu desenvolvimento que a profissão procurou desvincular-se do conceito caritativo passando a embasar sua suposta teoria em outras ciências sociais ou humanas sofrendo, com isto, as influências destas teorias.

A partir do exposto, é preciso destacar dois momentos característicos na profissão: a) a profissão como prática caridosa, benevolente, filantrópica e assistencial; b) a profissão em busca de uma especificidade dentro do campo das ciências humano-sociais.

Neste primeiro momento, considerando o Serviço Social no Brasil, necessário se faz situá-lo dentro de um contexto sócio-político. Segundo Sarmento (1994: 52), a implantação do Serviço Social no Brasil está diretamente relacionada às profundas transformações econômicas e sociais que ocorreram na época com a emergência da industrialização e da urbanização. $\mathrm{O}$ agravamento da Questão Social ${ }^{8}$ aumentou com o surgimento de um mercado de trabalho

\footnotetext{
${ }^{8}$ Conjunto das expressões das desigualdades sociais engendradas na sociedade capitalista, impensáveis sem a intermediação do Estado, como por exemplo: a ampliação do subemprego, do desemprego estrutural, a
} 
baseado nos moldes capitalistas, onde a exploração abusiva e a necessidade de controle das lutas foram as grandes características que impulsionaram o aparecimento do Serviço Social.

O surgimento da profissão estava ligado ao bloco da Igreja Católica que mobilizava-se para recuperar seus interesses e privilégios (tanto práticos, quanto ideológicos), muitos dos quais foram perdidos com a ascensão do conceito de hegemonia do Estado, da expansão do conhecimento cientifico e a tomada do poder pela burguesia. Na mesma proporção, as lutas operárias mobilizavam-se para confrontar com as políticas coronelistas do Estado. Martinelli (1989: 103) afirma que o Estado, percebendo a tensão entre os trabalhadores, traz para si próprio a responsabilidade de cuidar da reprodução da sua força de trabalho. Para isto realiza alianças com a Igreja e com os setores abastados da burguesia, com o intuito de dividir a tarefa de circunscrever a hegemonia do poder ao restrito âmbito da classe dominante.

É a partir da estratégia articulada para o enfrentamento da Questão Social ${ }^{9}$ entre o Estado e a Igreja que inicia-se o processo de surgimento de diversas instituições assistenciais. Este momento é marcado pelo surgimento das primeiras escolas de Serviço Social no país. Quem entrou em cena neste momento foi o Centro de Estudos e Ação Social de São Paulo CEAS, que realizou em 1931 o primeiro curso de preparo para o exercício da Ação Social denominado de Curso Intensivo de Formação Social para Moças ${ }^{10}$.

Neste período a produção de conhecimento na área era praticamente nula, só havia reprodução dos ensinamentos ideológicos de reprodução das relações sociais de produção capitalista, como estratégia para se expandir o capital ${ }^{11}$.

Já em 1936, foi criada a Escola de Serviço Social de São Paulo e, um ano depois, foi criada a segunda Escola de Serviço Social no país, situada no Rio de Janeiro. Agora com um cunho mais educacional, não mais como um simples curso rápido destituído de um comprometimento social e educacional. As Escolas chegaram para marcar oficialmente o início do estudo das ações sociais, no entanto, ambas tinham como base doutrinária a moral e os princípios doutrinários da Igreja Católica, fundamentando-se, já nesta época, as ações técnicas

informalidade, e em conseqüência o crescimento dos níveis de desigualdade e de pobreza. (IAMAMOTO, 2000: 54-58).

9 A questão social era vista de forma bastante reducionista, como manifestação dos problemas individuais, passíveis de controle através de uma prática social cada vez mais nitidamente concebida como uma atividade reformadora do caráter. (MARTINELLI, 1989: 109-110).

${ }_{10}$ Importante colocar que este curso foi totalmente importado do modelo franco-belga de Serviço Social, promovido pelas religiosas de Santo Agostinho e voltado para as moças da alta burguesia paulista. O curso foi ministrado pela assistente social belga Adèle de Loneux, da Escola Católica de Serviço Social de Bruxelas. (1989: 109-110).

${ }^{11}$ O Serviço Social nasceu de fatores que guardam relação com o surgimento do capitalismo: o desenvolvimento das forças produtivas na metrópole e o desenvolvimento das técnicas e da ciência. (FALEIROS, 1993:18) 
da profissão (SARMENTO, 1994: 52 e MARTINELLI, 1989: 107-108). Registra-se também a criação das escolas de Serviço Social que dão impulso na tentativa de regulamentação da profissão, porém somente em 1953 é que ocorrerá a regulamentação da profissão, através da lei 1.889/53, que também apresentará os objetivos do ensino do Serviço Social no Brasil, pautados na formação científica, técnica, prática e pessoal (AGUIAR, 1985: 33-34).

Partindo das influências de caráter religioso, não há como deixar de contrapor esta influência com a corrente de pensamento positivista que influenciou as ciências sociais e humanas na sua forma de explicar e compreender a realidade sob o enfoque racional e não mais religioso. Da mesma forma, o Serviço Social também sofreu influência desta corrente de pensamento, seguindo acriticamente suas orientações e ideologias.

Faleiros (1993: 65), ao analisar a influência positivista no Serviço Social, destaca que a prática profissional era considerada como um meio, uma mediação, um instrumento da sociedade, para alcançar determinado nível de bem estar, eliminando as disfunções, problemas de condutas desviadas, problemas de desadaptações e carências. Surge com isto "[...] a idéia do individualismo $^{12}$, que passou a predominar no imaginário social, onde as conseqüências pelo seu sucesso, mas principalmente pelo seu fracasso eram atribuídas ao próprio indivíduo, responsabilizando-o de todos os seus problemas" (SOUZA, 2004: 86).

Ora, como visto anteriormente, o positivismo tinha como fundamento básico a hipótese de que a sociedade poderia ser regida por leis naturais, universais, invariáveis que eram independentes da vontade humana, cabendo somente a regulação para a manutenção da ordem e do equilíbrio da sociedade. Com a influência marcada por este pensamento o Serviço Social serviu de instrumento para operacionalização da concepção positivista da classe burguesa, atuando como instrumento regulador e controlador das relações sociais.

Cabe destacar a função do pensamento de uma das mais importantes variações do pensamento positivista: o funcionalismo, esse coadunava com pressupostos baseados na individualização e a aceitação do problema, buscando a integração do homem com o meio. $\mathrm{O}$ funcionalismo trouxe por meio de seu método algumas técnicas para intervir na sociedade sem o cunho eminentemente caridoso. Importante este destaque, pois conforme coloca Souza (2004: 87) "o funcionalismo representa o esforço inicial de racionalização da assistência social até então prestada com base em princípios eminentemente religiosos”.

${ }^{12}$ Refere-se a idéia de que os sistemas sociais são constituídos primariamente de indivíduos e podem ser compreendidos em termos de suas opções, características e interesses (Johnson, 1997: 130). O que torna o indivíduo responsável por todas as suas atitudes, principalmente no que diz respeito à sua condição de pobreza e miséria. 
Iamamoto (1982: 207) argumenta que deve-se destacar a transição do Serviço Social essencialmente caritativo, para um Serviço Social mais especializado, ou seja, a caridade passa a utilizar recursos que a ciência e a técnica lhe oferecem; "[...] o Serviço Social representa uma evolução dos antigos métodos favorecida pelas descobertas científicas, pelo desenvolvimento dos estudos sociológicos e principalmente, pela intensidade e complexidade dos problemas sociais presentes".

Como a atuação do assistente social foi constituída com influências da concepção positivista-funcionalista, focou-se em uma ação setorizada, fragmentada e procedimental, desenvolvendo por meio de métodos a sua intervenção. Os três métodos incorporados historicamente ao assistente social foram: caso, grupo e comunidade ${ }^{13}$. O profissional era visto apenas como um operador de procedimentos e técnicas, por vincular o seu trabalho somente a estes métodos.

Sendo assim, o Serviço Social foi tratado como uma disciplina sujeita, ou melhor, subordinada, às outras ciências, por não desenvolver seus próprios conceitos, pois baseava-se somente em sua experiência. Como exemplo, Lima (1975: 25) destaca que "[...] o Serviço Social inseriu-se no campo da Patologia Social, tendo como comprovação empírica as primeiras Escolas de Serviço Social que tinham a função de formar um técnico de tratamento dos problemas da sociedade. Torna-se deste modo um para-profissional: para-médico, parapsiquiatra, para-psicólogo, para-juristas dentre outros "para" [...]". Destaca-se neste ponto uma das maiores características do positivismo que era a de pensar a sociedade como um corpo biológico.

É com base nesta concepção que Lima (1975: 25) afirma como o Serviço Social surgiu acobertado pela delimitação entre um conjunto de conhecimento sobre a sociedade e uma gama de procedimentos para modificá-la. Isto demonstra como a profissão utilizou conhecimentos socialmente acumulados e produzidos por outras ciências para aplicar à realidade social e à sua prática. Tal pensamento coaduna com o de Martinelli (1989: 103) quando coloca que a

\footnotetext{
13 "O Serviço Social considera o indivíduo como "um caso" (grifo nosso) que se estuda, buscando-se uma solução ao problema imediato: fome, habitação, etc., segundo certos recursos oferecidos pelo sistema.

Os grupos em Serviço Social são considerados como um conjunto de pessoas em interação, por intermédio dos quais se busca harmonizar os interesses, chegar ao consenso, à compreensão, a objetivos comuns, dentro do sistema. Estes objetivos são avaliados segundo princípios eternos e valores imutáveis, como a dignidade do homem e o bem estar ideal.

Pelo desenvolvimento de comunidade busca-se o consenso e a integração com o discurso sobre interesses comuns, problemas comuns, com o objetivo desenvolvimentista de melhora das condições de vida." (Faleiros, 1993: 24)
} 
Sociedade de Organização da Caridade $^{14}$ européia tratou de buscar reforços nas ciências sociais, notadamente na Sociologia, na Economia, e depois na Pesquisa Social, para embasarem sua abordagem grupal, em detrimento de uma abordagem mais individual.

E é em sintonia com estas influências das ciências sociais que surge o segundo momento da profissão, pois traz para o Brasil a constituição do Serviço Social vinculado a uma sociedade capitalista que inaugurava e legitimava uma modalidade de conhecimento erudito: o científico. Dentro deste segundo momento, diversos autores discutem sobre a influência das ciências sociais para o Serviço Social ${ }^{15}$, na tentativa de produzir teorias, metodologias, categorias, conceitos, enfim, conhecimento próprio do Serviço Social.

De acordo com Vieira (1981: 87) “[...] as influências, com outras teorias, não eram totalmente conscientes e decorria mais da necessidade de racionalizar sua atuação do que constituir suas próprias referências". Cabe aqui destacar que neste momento ainda não havia explicitamente a preocupação em pensar a construção de teoria e metodologia próprias. Esta tentativa de racionalização era mais um reflexo histórico das outras ciências que estavam se definindo e se reafirmando diante da sociedade, motivo pelo qual o Serviço Social incorporou bases teóricas de outras ciências para analisar o indivíduo, o grupo e a comunidade.

Já Lima (1975: 25) coloca que "a tarefa do Serviço Social dentro das ciências sociais limitou-se a generalizar no plano concreto as "verdades" descobertas pela sociologia, psicologia, economia, medicina, direito, etc". Ou seja, o Serviço Social na busca por produzir conhecimentos próprios, importou para seu bojo, o estudo e as concepções estigmatizadas como verdadeiras de outras áreas do conhecimento.

Segundo Faleiros (1993: 65), a prática do Serviço Social era considerada somente como uma mediação, um trabalho técnico, destituído de um conhecimento próprio, mas dependente do saber de outras ciências. Assim, foi principalmente com base nestas ciências: sociologia, sociopsicológicas, psicologia social, direito, filosofia que o Serviço Social questionou e aprimorou sua atuação e bases teóricas, adotando critérios de cientificidade para produção de seu conhecimento.

De acordo com o autor, a preocupação com o aspecto científico da ação profissional nasceu da própria crise na qual passava a profissão frente à constatação de sua ineficácia diante

\footnotetext{
${ }^{14}$ Instituição de expressivo prestígio fundada na Europa, mas aportes na América do Norte, no final do séc. XIX e início do séc. XX. Foi a instituição de maior porte no âmbito da assistência social e que adotava e difundia a idéia de assistência social como uma ação eminentemente de reforma do caráter.

${ }^{15} \mathrm{O}$ esforço de cientificização do Serviço Social começa com a incorporação da teoria funcionalista nas ciências sociais.
} 
dos problemas e também da mobilização das classes trabalhadoras. "Esta preocupação com uma base científica para realizar suas atividades foi a tentativa de superar o empirismo e o idealismo, frente aos desafios do subdesenvolvimento e da dependência" (1993: 84).

Percebe-se com isto que o Serviço Social historicamente buscou sua especificidade dentro das ciências humanas ou sociais pautado em um referencial teórico criado através da construção e desconstrução de seu objeto. Ou seja, o Serviço Social, ao longo de sua trajetória profissional adotou vários objetos, cada um correspondente a um momento histórico, político e ideológico e todos estes relacionados ao conjunto de problemas sociais, econômicos e políticos enfrentados pela sociedade capitalista.

Segundo Faleiros (2005: 13-18), estes objetos vão da "instituição da moral, higiene, ordem e articulação da harmonia social na relação Estado/Sociedade”. Advirta-se que tais objetos encontram suporte no conceito de "Questão Social" correlacionando-se com o desenvolvimento teórico do Serviço Social.

Hoje, ganhou hegemonia, mesmo que não consensual, o pressuposto de que a Questão Social em suas múltiplas expressões é o objeto privilegiado de estudo e intervenção do assistente social. Entretanto, há de se destacar que sua base teórico-metodológico também não está isenta de polêmicas e controvérsias. Atualmente, o Serviço Social busca sua unidade metodológica em contrapartida aos primeiros métodos de caso, grupo e comunidade.

Torna-se, assim, o enfrentamento da Questão social e suas múltiplas expressões o objeto privilegiado, mas não privativo do Serviço Social, "garantindo o fortalecimento das relações entre assistentes sociais e com as classes subalternas, com as lutas destes na perspectiva de desvendar seus interesses" (CARDOSO, 2000: 93), e assim auxiliá-los dentro de uma perspectiva coletiva e não mais como o problema de um indivíduo isolado.

É a partir do movimento de Reconceituação que se dá o marco na profissão. Trata-se do despertar para um questionamento da "ideologia do consenso", da "adaptação do indivíduo", ou da "harmonia social" (FALEIROS, 2005: 17) que o Serviço Social buscará reestruturar seu ser e fazer dentro de um eixo crítico aos tradicionais métodos de caso, grupo e comunidade.

Primeiramente não há que se falar em um movimento de Reconceituação uno, pois em cada país tomou aspectos diferentes para tratar do assunto, contudo, o que não se pode negar é o seu marco perante a profissão. Sarmento (1994: 113) afirma que "a reconceituação é entendida como um movimento teórico, metodológico e político que procurou criar uma identidade e unidade entre a sua ação e as demandas reais inerentes à atual situação da América Latina", ou seja, o Serviço Social inaugura um debate plural ideo-político. 
Destarte neste período a teoria marxista surgia dentro dos movimentos e lutas dos trabalhadores. Esta teoria seria o marco para a grande mudança. Partindo de uma concepção dialética da realidade, e não mais retilínea e ordenada como o positivismo pregava. Iamamoto (2005: 210-211) coloca que a descoberta do marxismo pelo Serviço Social latino-americano contribuiu decisivamente para um processo de ruptura teórica e prática com a tradição profissional. Este encontro com a perspectiva crítico-dialética se deu, basicamente, nas práticas político-partidárias e das militâncias políticas da prática profissional formando assim profissionais com compromisso político e consciência teórica (grifo da autora) capazes de explicar o processo social e as possibilidades de ação nele contidas.

Outra importante colocação é que esta alteração para uma trajetória crítica não se deu de forma equânime e não teve a adesão de todos os seguimentos da profissão, pois romper com toda a identidade antes assumida e perceber sua situação dentro de um processo produtivo foi difícil, ainda mais, quando se está alienado.

Tal movimento de conscientização, que emergiu na metade dos anos 60, na América Latina, prolongou-se por uma década, ficou conhecido como movimento de Reconceituação e representou um marco decisivo no desencadeamento do processo de revisão crítica do Serviço Social no continente. Foi uma denúncia de autocrítica que tinha como contra face um processo seletivo de busca da construção de um novo Serviço Social latino-americano ao mesmo tempo tinha como característica principal a contestação do tradicionalismo profissional, tanto em seus fundamentos ídeo-teóricos, quanto de seu modus operandi. (2005, 205-207).

Da mesma forma que não houve a total adesão ao movimento por parte dos assistentes sociais, surgiram também divergências de opiniões no que tange a participação no movimento de reconceituação, pois existiam raízes sociais e teóricas distintas formando assim uma grande miscelânea de opiniões que buscavam refletir um novo Serviço Social.

Diante destas diferentes concepções moldaram-se múltiplos marxismos, contudo nenhuma corrente fielmente marxiana ${ }^{16}$. Iamamoto (2005: 211-213) coloca que o universo teórico neste período foi marcado por fortes traços ecléticos, dando lugar a uma invasão do positivismo no discurso marxista. Esta bagagem eclética não foi capaz de operar a efetivação das intenções declaradas, fazendo com que a ruptura anunciada não fosse igualmente integrada. Assim, o movimento de reconceituação se viu prisioneiro de uma antiga contradição, já

\footnotetext{
${ }^{16}$ Estudos realizados a partir das obras de Karl Marx.
} 
denunciada por Lukács (apud Iamamoto): a coexistência de uma ética de esquerda e uma epistemologia de direita. Conclui-se, com isto, que existia o pensamento de ruptura com a alienação, contudo esta ruptura não foi radical, permanecendo traços conservadores da metodologia positiva.

A autora segue expondo que deste movimento originou-se um duplo dilema que até hoje permanece presente na prática profissional: o fatalismo e o messianismo ${ }^{17}$.

Hoje se vê claramente tal dilema entre os profissionais que aceitam a imposição de um poder institucional sobre sua ação profissional, justificando-se não poder questionar por estar dentro de um órgão ou instituição que normatiza todas as suas atribuições não podendo excedêlas. O outro profissional é aquele que está dentro de uma instituição mais tem claro seu compromisso ético com a ampliação de direitos, com as classes menos favorecidas, com todos que tem o seu direito cerceado de alguma forma, neste caso o profissional não se prende à normativa institucional, ele vai mais além, pois o seu compromisso com o indivíduo vai bem além do que um simples preenchimento de fichas.

Retomando à Reconceituação, Iamamoto (2005: 215-217) coloca que o embate com o Serviço Social tradicional se reverteu em uma modernização da profissão que atualiza sua herança conservadora. Enfim, não há como negar que não houve mudanças neste período, contudo, as mudanças serviram para reafirmar sua legitimidade junto às instâncias demandantes da profissão, que na época ampliaram-se consideravelmente.

Foi neste período, coloca a autora, que o Serviço Social foi embalado pela onda de cientificação de diversos conhecimentos, inseriu-se nos quadros universitários, ampliando suas unidades de ensino, tanto públicas quanto privadas. Iniciou a realização de pesquisas e as extensões universitárias, criando bases para nutrir sua produção científica e criando um mercado editorial quase inexistente na época. Expandiu-se a interlocução com as ciências afins e galgando a condição de parceiro válido no diálogo acadêmico, mais tarde reconhecido pelas entidades oficiais de fomento científico.

E nesta linha histórica Kameyama (1998: 33-34) afirma que foi a partir da década de 70 que iniciou-se, no Brasil, a preocupação com a produção de conhecimento na área do Serviço

\footnotetext{
${ }^{17} \mathrm{O}$ fatalismo, inspirado em interpretações que naturalizam a vida social, apreendida à margem da subjetividade humana, redundando em uma visão perversa da profissão concebida como totalmente atrelada às malhas de um poder tido como monolítico, resultando disso a impotência e a subjugação do profissional instituído.

Já o messianismo privilegia os propósitos do profissional individual, num voluntarismo, não permite o desvendamento do movimento social e das determinações que a prática profissional incorpora nesse movimento, ressuscitando inspirações idealistas que reclamam a determinação da vida social pela consciência. Iamamoto (2005: 211-213)
} 
Social, quando foram criados os primeiros cursos de pós-graduação nas áreas de ciências sociais e em especial, na área do Serviço Social. Despertou-se, neste período, a discussão sobre os fundamentos da cientificidade desta produção de conhecimento sem chegar a um consenso no que se refere a um possível paradigma. De acordo com o autor, o conhecimento científico forja condições específicas para a formação de profissionais, atribuindo-lhes autoridade para explicar e apreender os fenômenos sociais.

O movimento de Reconceituação, embora tenha sido em grande parte uma continuidade moderna da forma antiga de se pensar o Serviço Social, não pode ter esquecida sua contribuição na ruptura "parcial" do pensamento essencialmente positivista. Acredita-se que a categoria não possuía maturidade suficiente para tal mudança, contudo, foi o suficiente para que mais tarde os mesmos resgatassem as teorias marxistas e sobre elas fizessem críticas do próprio marxismo.

Conclui-se que o que aconteceu ao Serviço Social foi uma busca pela atribuição de autoridade à profissão por se tornar produtora de conhecimento com critérios científicos, e não mais ser reconhecida pelo simples tecnicismo e atividade exclusivamente prática. Não, agora o Serviço Social incluso dentro das Universidades, procurava produzir conhecimento, teorias e conceitos (influência das ciências) que permitiam discutir seu objeto, objetivo, metodologia além do aspecto ideológico inerente a profissão.

Esta mudança vai além de uma simples modificação na trajetória profissional, significa uma "auto-crítica" e um "amadurecimento" na intelectualidade do Serviço Social, tal como destaca Souza (2004: 92) “[...] se torna um avanço no âmbito da reflexão teórico-metodológica e prático-reflexiva". A perspectiva marxista e principalmente a marxiana conseguem trazer para o bojo da profissão uma apreensão da universalidade e da totalidade da dinâmica da sociabilidade humana. Retira-lhe, ou pelo menos tentar retirar, a visão fragmentada e naturalizada dos problemas sociais, conduzindo-a para uma prática crítica, entendida como uma "especialização do trabalho coletivo, inserido dentro de uma divisão sócio-técnica do trabalho" (2004: 97). E não mais como uma disciplina que somente aplica o conhecimento produzido pela ciências sociais, para tentar ocupar uma posição privilegiada, na busca de um estatuto científico próprio.

O problema histórico de conceituar o Serviço Social como profissão eminentemente pragmática induziu a percepção de que não existe uma teoria do Serviço Social, ou seja, um conhecimento científico próprio. Tal problema, que apesar de transparecer superado, ainda 
gera grande discussão entre os intelectuais do Serviço Social a cerca da cientificidade ou não do Serviço Social e principalmente de uma especificidade, de um objeto próprio da profissão.

Há de se distinguir aqui primeiramente dois pontos cruciais, que são: a produção científica e a produção de conhecimento próprio do Serviço Social, pois ambas acabam por serem confundidas. A primeira refere-se à produção de conhecimento científico no Serviço Social; já a segunda se refere à produção de um conhecimento que tenha objeto, teoria e metodologia próprios do Serviço Social.

À guisa de exemplificação de tal temática apresentar-se-á dois autores que problematizam e polemizam a questão da cientificidade do Serviço Social. Para efeitos desta análise tomou-se como ponto de referência os textos de Boris Aléxis Lima, Contribuição à metodologia do Serviço Social (1975), e de Helder Boska Sarmento, Instrumentos e Técnica para o Serviço Social, elementos para uma rediscussão (1994), e para finalizar um texto de José Paulo Neto, Capitalismo Monopolista e Serviço Social (1996), que trata da impossibilidade de produção de conhecimentos próprios do Serviço Social.

O primeiro autor destaca uma alternativa metodológica de intervenção na realidade, baseado no modelo geral da dialética marxista. Mas, antes de colocar o posicionamento do autor, interessante destacar, brevemente, como ele divide as fases do Serviço Social em:

a. Fase Pré-técnica - caracterizado pelo espírito da caridade, beneficência, solidariedade e filantropia, onde se procurava solucionar situações e problemas particulares. Tal caridade era realizada pela classe dominante: a Igreja e os senhores feudais que procuravam a todo custo ter o domínio das massas e garantir a ordem vigente.

b. Fase Técnica - define pelo desenvolvimento do capitalismo e a transição das sociedades pré-industriais ao capitalismo industrial. Momento em que agravou o processo de mendicância e exclusão. Nesta fase, alterou-se a classe dominante para a burguesia e também a forma de controlar as disfuncionalidades sociais através das leis dos pobres "Poor Law", que era um sistema primitivo de seguro social para atender às necessidades individuais. Destaca-se que a ciência ainda estava com os resquícios do domínio da Igreja, desabrochando para a sua autonomia.

c. Fase Pré-científica - é determinada pela tendência asséptica ${ }^{18}$ onde o profissional conduzia-se por uma orientação que se circunscrevia aos limites da ciência. Sua formação

\footnotetext{
${ }^{18}$ Segundo o autor, trata-se de um procedimento destinado a produzir e conservar uma adaptação cada vez mais eficaz entre recursos disponíveis e necessidades em matéria de bem-estar social dentro de uma zona geográfica ou esfera funcional. (1975: 62)
} 
técnica baseava-se em seu aperfeiçoamento como instrumento útil à classe dominante, sendolhe vedado adotar posturas ideológicas que levassem ao questionamento de sua fundamentação filosófica e de seu caráter instrumental. O Serviço Social já detinha um instrumental completo fornecido pelos três métodos (caso, grupo, comunidade). A profissão estava alheia a qualquer movimento político, preocupando-se somente em ajustar seus "clientes" (grifo nosso) a uma determinada estrutura social.

d. Fase Científica - o Serviço Social inicia esta fase quando começa a indagação das relações causais das necessidades que enfrenta, passando a preocupar-se com a essência dos problemas, incursionando no interior dos fenômenos buscando apreender a natureza contraditória e substancial que os explica. Ou seja, é a fase reflexiva e racional da disciplina, permitindo-lhe transcender o marco da experiência imediata e pragmática.

Interessante é a colocação destas fases para explicitar como o autor toma as passagens do Serviço Social e como conclui a última fase que é, em questão, a mais importante por tratar da cientificidade do Serviço Social. O autor defende que para o Serviço Social chegar a esta fase deve opor-se à metodologia tradicional (positivista), a fim de tomar como nova metodologia a postura dialética que toma a realidade como uma totalidade ${ }^{19}$ e não como fatos isolados. O autor define o Serviço Social em uma linha de comprometimento com a realidade social, considerando como objeto a "ação social do homem oprimido e explorado" inserido no seu contexto social, uma vez que o indivíduo isolado é considerado uma abstração (1975:83).

Dentro da viabilidade científica do Serviço Social, o autor destaca a relação entre a teoria e a prática, que devem ser visualizadas em duas dimensões: um conhecimento teórico e um conhecimento prático, fundido em um conhecimento científico.

O autor coloca que a falha do Serviço Social foi em não teorizar suas ações, ficando apoiadas somente em princípios e conceitos de outras disciplinas e também de correntes científicas, pois sem elaborar seus conceitos continuará na fase pré-científica. A profissão ficou restrita a prática-prática, ou seja, a prática empírica, sem conceitualizar e organizar seu conhecimento, sem questionar o objetivo para qual foi criada, sem criticar a corrente positivista que o circunscreveu, os modelos teóricos que a formaram e a sociedade para qual servia.

\footnotetext{
${ }^{19}$ Reflexão marxista dentro do discurso dos autores mais atuais. A totalidade não é a soma das partes, mas um grande complexo constituído de complexos menores (reciprocidade da ação).
} 
Lima (1975: 87) defende a possibilidade de produção científica própria por parte do Serviço Social, contudo para se produzir conhecimento científico a profissão deve criar a capacidade de elaborar um marco teórico. O autor argumenta que:

"[...] a teoria é guia da ação e ação cede lugar ao conhecimento teórico. [...] A prática exige um marco teórico, conceitos, conhecimentos específicos. A teoria fundamentada na experiência prática, instrumentaliza a intervenção da realidade. A realidade social torna-se a base para a elaboração de teorias e ao mesmo tempo área de aplicação das mesmas, numa dinâmica transformadora e de transformação constante". (LIMA, 1975:87).

Para o autor, é fundamentalmente através da prática que se adquire conhecimentos capazes de viabilizar cientificamente a teoria do Serviço Social implicando em "[...] fundamentar a teoria na práxis social, sendo seu reflexo e não mera adaptação de teorias prévias. Só assim será possível uma relação estreita entre ambos os níveis de conhecimento. Em totalidade, o conhecimento se consegue atuando e, nesta medida vai-se conhecendo" (1975: 87).

Ao discorrer sobre a viabilidade cientifica, o autor se baseia no pensamento dialético onde teoria e prática devem andar juntas com o fito de promover uma ação transformadora e não apenas reprodutora e subsidiária de outros conhecimentos.A sua proposta metodológica consiste em contrapor os métodos tradicionais, ainda usados pelo Serviço Social, na tentativa de inscrever novas bases para o Serviço Social objetivando que o mesmo consiga estruturar seu marco teórico próprio, que lhe permita a reformulação de sua prática, libertando-se das amarras limitadoras do positivismo e da simples repetição e manutenção da ordem social.

Diante do exposto, acredita-se que o Serviço Social ao conseguir reformular sua metodologia e produzir conceitos próprios estaria habilitado a produzir conhecimento específico. Contudo, é importante situar historicamente a perspectiva do autor, pois percebe-se que tais argumentos foram afirmados na época em que o Serviço Social estava no ápice da reconceituação e principalmente na busca por um estatuto de cientificidade de seus conhecimentos. Nesta época, como dito anteriormente, angariava-se o status de científico em todas as disciplinas para estas terem reconhecimento e legitimidade perante as outras formas de conhecimento.

Ao fazer considerações referentes à questão da produção científica situada na obra de Lima, Chacur (1983: 91-92) afirma que o modelo analisado pelo autor não representa uma proposta de intervenção na realidade social que resulte efetivamente capaz de viabilizar o 
Serviço Social como prática transformadora da realidade, onde a profissão não possui respaldo teórico para convertê-lo em prática de intervenção, muito menos para transformá-lo em conhecimento científico. A autora não toma um posicionamento nem a favor nem contra a possibilidade do Serviço Social produzir conhecimento científico, só coloca que para tratar a questão polêmica da cientificidade da profissão, há de se ter um tratamento adequado quanto à sua reflexão epistemológica rigorosa sobre a especificidade do tipo de prática que o Serviço Social pretende desenvolver. É a partir desta reflexão que se estabelecerá limites, como prática teórica, para produzir teoria do real (grifo da autora), e descobrir os limites que lhe são impostos, a fim de informar uma prática profissional mais racionalizada e eficaz para o assistente social.

Quem advoga em oposição à possibilidade do Serviço Social produzir conhecimento científico é Sarmento (1994: 211) ao ressaltar que o "Serviço Social não se constitui como uma ciência social, mas, sim, como disciplina derivada desta. Fazendo com que a profissão aproprie-se das teorias sociais dispostas às profissões e, ao fazê-lo, busque sistematizar suas estratégias de intervenção". Ou seja, o Serviço Social não possui um estatuto teórico ou científico e a sua especificidade, segundo o autor, estaria dada não por uma teoria própria, ou um método próprio, mas pela sua institucionalização como atividade determinada na divisão social e técnica do trabalho.

$\mathrm{O}$ autor ainda argumenta que por ter se firmado como profissão da prática, o Serviço Social privilegiou a sistematização de procedimentos ${ }^{20}$, que particularizados apresentam um dado conjunto de conhecimentos orientadores de ações. Mas que tenta a todo custo retirar esta especificidade prática para inseri-la além do praticismo, pensando esta intervenção dentro dos quadros complexos que constituem esta totalidade da vida social e sob o crivo da criticidade (totalidade e histórico). Dentro desta prática existe um conhecimento prático que se pretende elaborado teoricamente enquanto disciplina ${ }^{21}$. (1994: 233 e 236).

E para finalizar tal colocação, imprescindível se faz destacar a especificidade da profissão para o autor, que destaca:

"sendo o Serviço Social uma disciplina de intervenção na realidade social, seu conhecimento é voltado fundamentalmente a sua operacionalização. A prática

\footnotetext{
${ }^{20}$ Procedimentos eminentemente práticos como, por exemplo, fazer encaminhamentos e preencher fichas de triagem.

21 Sarmento entende que o Serviço Social vem construindo conhecimento, no entanto, seus profissionais não tiveram competência para sistematizá-lo e organizá-lo enquanto uma teoria particular. (1994: 236)
} 
profissional processa uma constante organização e reorganização de conhecimentos na imediata transformação para sua ação". (1994: 238).

Muito próximo do que defende Sarmento situa-se a análise de Netto. Segundo ele, o Serviço Social possui o estatuto fundamental de atividade que responde, no quadro da divisão social e técnica do trabalho da sociedade burguesa consolidada e madura, a demandas sociais prático-empíricas. Ou seja, em qualquer hipótese, o Serviço Social não se instaurará como núcleo produtor teórico específico - permanecerá profissão, e seu objeto será um complexo heteróclito de situações que demandam intervenções sobre variáveis empíricas (1993:147).

Tal argumentação dá ênfase ao tipo de prática dominante, a empírica, descartando todo e qualquer processo de elaboração teórica e metodológica. "[...] Esta argumentação não cancela a produção teórica dos assistentes sociais que suporá a sistematização da sua prática". Entretanto, a superação do ecletismo teórico ${ }^{22}$ implica a interdição de qualquer pretensão do Serviço Social posicionar-se como um sistema original de saber, como portador de uma teoria particular referenciada à sua intervenção prático-profissional, cabendo somente um "sistema de saber de segundo grau" (1993: 147).

Para chegar a tal conclusão, o autor expõe que o Serviço Social dentro da evolução das ciências sociais tornou-se subproduto desta, ou seja, ficou na condição de subalternidade técnica, ou marginalidade teórica, levando a total dependência teórica, o que leva a conseqüências desastrosas, pois o profissional fica na condição de receptor de outros saberes e não consegue produzir seus próprios saberes.

Diante do exposto viu-se quão polêmico é o posicionamento de o Serviço Social ser ou não ciência, ou de produzir ou não conhecimento específico. Lima (1975: 64) defende a possibilidade do Serviço Social ser ciência, desde que adote uma metodologia de intervenção própria baseada na realidade. Enquanto Sarmento (1994: 211) resguarda que o Serviço Social é somente uma disciplina de intervenção na realidade social, não possuindo arcabouço teórico capaz de produzir ciência. E, por fim, Netto (1996) defende a impossibilidade de o Serviço Social formular saber específico próprio pelo motivo de sua trajetória na produção de saber ficar restrita à recepção de outros saberes.

Estas diferenciações tiveram como intuito demonstrar o desacordo dos intelectuais do Serviço Social com respeito a esta temática. Diante de tais posicionamentos concordamos com

\footnotetext{
${ }^{22}$ O Serviço Social é considerado como receptor da produção dos saberes especializados das ciências sociais. O sistema de saber da profissão fica profundamente comprometido erguendo-se em um campo eminentemente eclético, tendendo a ser bastante heteronômico. (NETTO, 1996: 143 - 145)
} 
a afirmação de Faleiros (2005: 69) quando diz que a construção do conhecimento científico é polêmica, mas é através da ruptura com os supostos reducionistas, teologistas e empiristas que é possível construir novos objetos de intervenção, pautando através das construções teóricometodológicas que advêm da teoria pela prática e da pratica pela teoria, não reduzindo a uma teoria abstrata, mas que implica em uma acumulação de experimentações controladas por um saber sistemático, combinando investigações quantitativas e qualitativas e com análises críticas das mesmas.

O autor ainda coloca que não se pode reduzir a intervenção social a um único modelo, a uma teoria exclusiva, pois se estaria realizando um processo unilateral que não leva em conta a historicidade dos processos, a especificidade e a dinâmica de cada conjuntura. (2005: 69). Ou seja, o reducionismo teórico desconsidera os sujeitos, a história, a crítica e a realidade social. É com a crítica teórica que se articula as mediações práticas e conseqüentemente a prática da crítica. O autor expõe que “[...] a prática profissional só deixará de ser repetitiva, pragmática e empirista se os profissionais souberem vincular as intervenções no cotidiano a um processo de construção e desconstrução crítica e autocrítica do conhecimento e da intervenção”.

Chega-se, então, a uma importante característica do Serviço Social: a sua necessária capacidade auto-reflexiva enquanto profissão, frente às experiências práticas com um espaço social que se recusa a ser entendido como um mero objeto de conhecimento teórico ou somente como prática profissional.

No nosso entendimento, o Serviço Social é tido como disciplina científica, pautado pela investigação e intervenção na Questão Social, questão esta primordial à sua agenda de estudos, baseada nas relações sociais concretas. Esta profissão adotou e adota ao longo de sua trajetória um saber baseado em critérios técnico-operativos, teórico-metodológicos, e ético-políticos. E é através destes referenciais que o assistente social embasa seu conhecimento, busca seu reconhecimento e procura firmar-se teórica e metodologicamente no campo das concepções e profissões que intervem na realidade social.

Ressalta-se, no entanto, que a discussão sobre a prática profissional não pode ser apreendida apenas a partir de uma ação ou teoria autônomas, mas sim de uma prática elaborada a partir de uma correlação entre ambos, e que se aporte na instrumentalidade da profissão, que a fundamenta. 


\subsection{Sobre a instrumentalidade no Serviço Social.}

O Serviço Social, mesmo buscando uma unidade entre conhecimento e ação, apresenta sua intervenção segundo Pereira (1988: 01) como a causa finalis da relação teoria versus empiria, mediada pela investigação que dá sentido à ação e oferece uma visão de conjunto das múltiplas determinações da situação a modificar. E o resultado desta relação é a famosa frase "conhecer para transformar".

De acordo com Sarmento (1994: 216), toda a atividade humana é composta por uma atividade de consciência (teórica), mas que não pode por si levar a uma transformação da realidade, ou seja, requer acima de tudo a sua objetivação (prática). Segundo o autor, a práxis pressupõe duas modalidades de atividades: uma teórica e uma prática. A atividade teórica não é per si, uma forma de práxis, pois consegue transformar representações e conceitos, mas nunca a realidade. Mas ela é fundamental, pois é a ela que corresponde a produção de objetivos e conhecimentos indispensáveis para transformar a realidade, ou é através dela que se traça finalidades que antecipam idealmente a transformação desta realidade. Sendo este o motivo pelo qual destacou-se nos capítulos anteriores a discussão sobre a produção de conhecimento teórico do Serviço Social.

Sob o ponto de vista do Serviço Social, é através de seu objeto e da utilização de seu instrumental que se realizará modificações, ou seja, através da sua atuação que se obtém o fim último do Serviço Social - a transformação da realidade social.

Percebe-se que a teoria e prática possuem uma unidade, mas é na prática que se tem um fundamento e finalidade da teoria. Sarmento coloca que a relação está precisamente entre uma teoria já elaborada e uma prática que ainda não existe. A prática é tratada como objeto de reflexão, exige uma ação que ainda não existe e, deste modo, a teoria (como projeto) determina a prática real e efetiva (1994: 218). Daí a preocupação do movimento de reconceituação em promover a reflexão sobre suas bases internas para, a partir daí, realizar ações de cunho crítico e não alienados. Como visto anteriormente, este movimento procurou alterar o estigma da profissão com caráter estritamente interventivo e pragmático.

Neste sentido, Guerra afirma que há quase um consenso estabelecido pela categoria de que a evolução da profissão pós-reconceituação fecundou em um único sentido: o do aprofundamento teórico-metodológico em detrimento da prática profissional (1999: 23).

A discussão a respeito de o Serviço Social ter o cunho eminentemente pragmático ou teórico é grande e não existe consenso sobre tal definição. Contudo, não pode deixar de se 
registrar que o Serviço Social possui caráter particular perante outras profissões, onde "a intervenção constitui o eixo em torno do qual giram todas as atividades profissionais, inclusive a pesquisa teórica", constituindo assim seus elementos essenciais para a formação e reconhecimento do Serviço Social. (PEREIRA, 1988: 04).

Isto demonstra quão estão interligadas a teoria e a técnica. No entanto, há de se destacar que a concepção de ciência moderna se afasta um pouco desta interligação e cria uma divisão entre o pensar e o agir. É a partir deste impasse que se criou ao longo da história o binômio entre ciência e técnica. Esta segmentação deixou seu marco tanto nas ciências naturais quanto nas ciências humanas. A técnica foi reduzida a um papel servil de subordinação à ciência, pois essa já detinha o status de poder, de conhecimento irrefutável que sobrepunha a um mero fazer humano.

Todavia, esta perspectiva de subordinação é totalmente despropositada diante da importância que possui a técnica para a produção do conhecimento. Técnica é apontada por Sarmento (1994: 227) como a criação, enquanto desdobramento da racionalidade, pois a consciência tem participação ativa, uma vez que elabora finalidades e produz conhecimentos. Entretanto, a técnica não pode estar isolada da teoria, pois se isto acontecer, tornar-se-á somente uma prática repetitiva, isolada, limitando-se aos limites da aplicação mecânica.

A produção de conhecimento não se realiza somente nos planos das idéias, nem somente no plano do fazer, da técnica, pois uma produção teórica, sem uma técnica de aplicação, se torna uma teoria vazia, e uma técnica desprovida de respaldo teórico torna-se uma prática alienada e repetitiva, por não ter aparato em uma teoria e a reflexão da mesma. Cada uma (técnica e teoria) contribui para a produção de conhecimento mais completa e mais próxima da realidade.

De grande pertinência cabe ressaltar o valor da técnica, pois como bem fala Sarmento (1994: 227), a técnica não é só criação enquanto fato em si mesma, mas, é dimensão existencial da criação da vida social, enquanto elemento da constituição do mundo humano, da própria organização para com o mundo. A técnica não é um fato isolado, corresponde a um conjunto próprio de determinada cultura, pois, perderia seu sentido técnico se separada do conjunto sócio-político-econômico dentro de um determinado momento histórico.

O conceito de técnica dado por Trindade (2001: 23) está associado aos potencializadores do trabalho e pode ser definida no sentido de ser a "habilidade humana de fabricar, construir e utilizar instrumentos”, sendo então uma qualidade atribuída ao instrumento para que se torne o mais utilizável possível. 
A técnica é própria da constituição organizativa do mundo. Hoje é claro perceber esta organização, onde a técnica assume um papel de destaque na produção tecnológica, evidenciando o impacto que a mesma impõe sobre determinada nação, diferindo quem utiliza ou não suas técnicas avançadas na produção e expansão de conhecimento.

Em uma perspectiva analítica, histórica e teórica Trindade (2001: 21) afirma que o instrumental técnico é condição de parte da intervenção do Serviço Social, mas não como um arsenal de instrumentos e técnicas. Não pode limitar o instrumental a um rol de instrumentos e técnicas que seriam suficientes para a eficiência da ação.

Importante aqui distinguir a técnica de pura utilização de instrumentais. Pois, como dito acima, técnica é a criação ou até mesmo uma arte. Não pode ser reduzida à aplicação de meros instrumentos, sem a audácia de superar a si mesma e transpor, de forma racional e criativa, o tecnicismo. Quando se considera a técnica como uma simples instrumentação, é meramente construir e perpetuar a separação (alienação) dos produtores em relação ao produto "comum" e ao processo de trabalho. (GORZ apud SARMENTO 1994: 231).

E é a partir desta diferenciação da técnica ser pura instrumentação que se pode tomar o conceito ainda maior que abrange toda a intervenção do assistente social que é o conceito de instrumentalidade.

Guerra (1999: 53) afirma que a instrumentalidade no exercício profissional refere-se a uma determinada capacidade ou propriedade constitutiva da profissão construída e reconstruída no processo sócio-histórico, e possibilitam o atendimento das demandas e o alcance de objetivos profissionais e sociais, constituindo uma possibilidade concreta de reconhecimento social da profissão. Ou seja, é a capacidade de construção e reconstrução da trajetória da profissão pelos seus profissionais tanto através de sua teoria como da prática. A autora ainda afirma que na instrumentalidade encera-se uma postura teleológica, o que possibilita ao homem manipular as coisas a fim de atribuir-lhes propriedades verdadeiramente humanas, no intuito de converterem-se em instrumentos/meios para o alcance de suas finalidades.

Neste momento é interessante destacar a diferença entre instrumentalidade e instrumentação, conceitos que sempre trazem confusões. O primeiro refere-se a capacidade que o assistente social vai adquirindo de modificar, transformar e alterar as condições objetivas e subjetivas e as relações interpessoais e sociais existentes num determinado nível de realidade social. A instrumentalidade possibilita que os profissionais objetivem sua intencionalidade em respostas profissionais (1999: 53). Já o segundo conceito trata-se de um conjunto de instrumentos e técnicas utilizados para a consecução de suas finalidades. 
A instrumentalidade é tratada pela autora como uma mediação que permite a passagem das ações meramente instrumentais para o exercício profissional crítico e competente. Para isto, deve-se reconhecer a profissão como totalidade, ou seja, constituída de dimensões técnicoinstrumental, teórico-intelectual e ético-político. É a instrumentalidade tida como uma particularidade da profissão, pois permite a passagem do referencial técnico, teóricos, valorativos e políticos para sua concretização, de modo que estes se traduzam em ações profissionais, em estratégias políticas, em instrumentos técnicos operativos. Ou seja, permite que os sujeitos em face da sua intencionalidade invistam na criação e articulação dos meios e instrumentos necessários a consecução das suas finalidades profissionais (1999: 61).

Guerra (1999: 61) explana que para realizar esta definição das finalidades e da escolha dos meios e instrumentos mais adequados ao alcance das mesmas, o profissional dispõe de um acervo cultural que orienta as escolhas técnicas, teóricas e ético-políticas, incorporando conteúdos teórico-crítico. Com isto, o assistente social pode através do domínio deste acervo cultural negar a ação puramente instrumental, imediata, espontânea e a reelaborar em nível de respostas mais qualificadas e menos alienadas.

Sendo o Serviço Social uma disciplina de intervenção na realidade social, seu conhecimento volta-se para a operacionalização de um trabalho pautado pelo instrumental técnico-operativo utilizado por esse profissional. Esse instrumental, como já dito, não compreende apenas o arsenal de técnicas utilizadas para a efetivação do serviço, mas também o arsenal teórico-metodológico (conhecimento, valores, herança cultural, habilidades). Essa base teórico-metodológica é constituída pelos "recursos essenciais que o assistente social aciona para exercer o seu trabalho" (JESUS, 2004:65 apud IAMAMOTO 1997: 43), a fim de iluminar a leitura da realidade, direcionar melhor sua ação e moldá-la.

Segundo Jesus (2004: 65) a apropriação do referencial teórico metodológico, pelo assistente social permite-lhe apreender a realidade numa perspectiva de totalidade, e construir mediações entre o exercício profissional comprometido e os limites da própria realidade.

Os instrumentais técnico-operativos são considerados elementos intrínsecos à intervenção dos assistentes sociais, ou seja, essenciais para a efetivação do trabalho, pois estes “mediam e potencializam ações" (FÁVERO, 2005:120). O assistente social deve ter o domínio da utilização correta dos instrumentais, pois é através deles que se operará a intervenção frente as suas demandas.

A autora coloca que os instrumentais são variados e não necessariamente específicos de uma área (2005: 120). Importante ressaltar que não há instrumentais exclusivos ou privativos 
do Serviço Social. A diferença está na intencionalidade engendrada na utilização da técnica e depende dos fundamentos teórico-metodológicos e do compromisso ético-político que norteiam o projeto profissional de cada área do conhecimento.

Destaca-se que os pareceres, e os relatórios "sociais" são considerados como os principais instrumentos técnico-operativos utilizados pelo assistente social no âmbito do judiciário e têm sido objetos de estudos e pesquisas no contexto do Serviço Social no Judiciário. 


\section{CAPÍTULO III}

3.O parecer social como instrumento de poder do assistente social do Judiciário.

\subsection{A CEPEMA como lócus de pesquisa}

Não se consegue conceituar um verdadeiro Estado democrático de direito sem a existência de um Poder Judiciário autônomo e independente e, dentro da célebre separação dos poderes $^{23}$, coube o terceiro poder ao Judiciário. De acordo com Grinover (2002: 158), o Poder Judiciário é uno, e sua função precípua é solucionar os conflitos que surgem no bojo da sociedade e para isto realiza a prestação jurisdicional, constituindo-se como espaço disciplinador e controlador.

Mas antes mesmo de falar do meio institucional de solução de conflitos deve-se antes falar como se constituem estes. Os conflitos, por serem criados pela sociedade através de suas relações e interações, podem ter naturezas diversas, podem ser: conflitos entre indivíduos, entre grupos, entre vizinhos, entre nações, com o fito de resolverem principalmente questões particulares, públicas, patrimoniais ou liberdades diversas.

Cabe ressaltar que a solução dos conflitos sociais pela via judiciária é uma das formas de solução de conflitos, mas não é a única, pois, tal como afirma Souza (2006: 02) "os conflitos sociais produzidos e reproduzidos são de natureza múltiplas e os mecanismos de resolução também os são. Ou seja, a resolução pode se dar por vias institucionais e não institucionais". O judiciário é considerado como a forma socialmente mais reconhecida de resolução dos conflitos, pois, dentro das relações sociais, a primeira tentativa de acordo se dá fora da justiça e, somente se for infrutífera tal tentativa, é que se buscará intervenção da justiça.

"O poder disciplinador do judiciário tentar criar hábitos e elaborar ritos que permitam o máximo de homogeneização dos comportamentos" (AGUIAR, 1990: 68), inculcando hábitos que possibilitem o controle do cidadão, mas que também os recompensa na medida em que vai

\footnotetext{
${ }^{23}$ A idéia iluminista da tripartição dos poderes estatais de Montesquieu se fundamentou na separação dos poderes em Executivo, Legislativo e Judiciário, sendo que o Executivo tem a função de conversão da Lei em ato individual e concreto (função Administrativa), executar as leis e administrar o bem, o Legislativo teria função básica é de a elaboração da Lei (função normativa), o poder judiciário aplicaria as leis aos litigantes (função Judicial).
} 
incorporando permissões e obrigações, ou seja, sanciona condutas e comportamentos reprováveis e premia os comportamentos aprovados por um disciplinamento prévio.

E para exercer suas atribuições de poder, precisa controlar ou regular os destinatários do disciplinamento. Para este controle criam-se normas, leis, sanções para controlar os “interesses cristalizados ideologicamente” (1990: 72).

O vocábulo judiciário está ligado à expressão latina juris + dictio, que significa dizer o direito, ou seja, interpretar as leis para solucionar os casos que lhe são trazidos. Este Poder tem como precípua atribuição o controle e salvaguarda da lei justa e correta, compatível com a realidade histórica, com os princípios da legalidade e igualdade e com as tradições da sociedade, garantindo assim o direito das pessoas e promovendo a Justiça, aplicando as leis em questões nos diversos âmbitos: Constitucionais, Civis, Penais, Federais, Trabalhistas, Eleitorais, Militares (GRINOVER, 2002: 161).

Para o Judiciário exercer a sua função ele precisa ser motivado, ou seja, os interessados e envolvidos em litígios acionam-no para a resolução dos conflitos, salvo na ação penal pública $^{24}$. Na maioria dos casos esta demanda se dará na primeira instância sendo aquela que primeiro analisa e julga um caso apresentado ao Judiciário, geralmente representado pelos Juízes monocráticos.

Como foi visto acima, a finalidade do poder judiciário é disciplinar, regular e controlar as relações sociais, dentro da divisão jurídico-legal (constitucional, criminal, civil, infracional). Contudo, é na esfera criminal que a finalidade de controle e punição é vista de maneira mais explícita, pois é ao transgredir um determinado ordenamento jurídico que o indivíduo sofrerá uma sanção disciplinadora, que desembocará em uma pena. Este controle punitivo se dá em um meio institucional que, muitas vezes, não acompanha as mudanças sociais, repetindo procedimentos burocratizados e distantes da realidade.

O Judiciário é considerado por muitos autores como uma organização formal, complexa e hierarquizada, que produz e reproduz ritos processuais, revestidos por relações de saberes e poderes, correlações de forças, que definem ações, interações e práticas (SOUZA, 2004).

Assim, caracteriza-se pelo excesso de formalismo e burocratismo refletindo no que sentem denominado de "crise do judiciário",25. Sbabo (2005: 67) aponta que a crítica está no modelo predominantemente positivista que engessa o progresso da norma, conservando-a

\footnotetext{
${ }^{24} \mathrm{Na}$ ação penal publica espontânea a autoridade inicia o inquérito de ofício, sem provocação, espontaneamente. (Art. 5o , I do Código Processo Penal - Decreto-lei n ${ }^{\circ} 3.689$, de 03 de outubro de 1941).

${ }^{25}$ A se falar em crise do Judiciário fala-se em um momento histórico, no qual tal poder entra em descrédito e descrença da população, por não conseguir solucionar com rapidez os litígios existentes na sociedade.
} 
somente como padrão de conduta, com ameaça de sanções organizadas. Este modelo não permite que a lei ultrapassada se adeque às transformações contínuas da sociedade, impondo procedimentos e limites que chegam a ser irracionais.

Esta visão positivista isola a norma jurídica da sociedade, separando o direito da realidade das relações humanas, tolhendo a discriminação e valorização das forças sociais relevantes à criação do Direito, bem como o cotejo dos valores nele expressos com outros eventualmente mais aptos a realização dos fins nele implícita ou explicitamente proclamados. (2005: 67)

A relevância da ciência do Direito é inquestionável sendo indispensável à interpretação e aplicação do direito. Entretanto, o que realmente deve ser valorizado é o modo e os limites segundo os quais se realiza. Contrariamente ao modelo positivista, precisa ser criativo e sensível ao quadro histórico a que se destina, logo, tornando-se necessário desvincular-se da limitação da norma imposta e sinalizar as particularidades do caso concreto. Deve-se adequar a norma à realidade.

Diante disso, a prestação da função jurisdicional brasileira fica condicionada às necessidades sociais e judiciais ${ }^{26}$, levando a Ciência do Direito a requerer o auxílio das Ciências Humanas e Sociais, ou seja, demanda-se cada vez mais o saber técnico especializado de profissionais de outras áreas do conhecimento humano sociais com o objetivo de assessorar e subsidiar as decisões e os procedimentos jurídicos em situações nas quais o conhecimento técnico-jurídico especializado é necessário (CHUAIRI, 2001: 136). Promovendo assim, um trabalho mais próximo da realidade, com outras áreas do conhecimento - Serviço Social, Psicologia, Sociologia, Pedagogia, entre outras.

Chuairi (2001: 137) afirma que a consecução de um trabalho interdisciplinar com ações compatíveis com a realidade social possibilita maior eficácia à ordem jurídica, superando, assim, a mera identificação da ciência do Direito com a aplicação da lei.

A atuação de outras áreas do saber dentro do Judiciário é relativamente recente e reflete um duplo movimento. Em primeiro lugar, a expansão e complexificação das funções sociais, políticas e institucionais da justiça brasileira (na busca por uma justiça nova), associada ao movimento de redemocratização do país, pós 1988; e em segundo lugar um movimento interno ao Serviço Social, com o surgimento de um posicionamento de crítica aos preceitos da

\footnotetext{
${ }^{26}$ A sociedade desperta para a sua condição de sujeitos de direitos e aumenta o interesse para questões que envolvem a justiça, acrescendo progressivamente o número de demandas às instituições jurídicas à procura de soluções para seus conflitos não resolvidos nas outras instâncias sociais.
} 
Reconceituação, baseado no marxismo, que permitiu revelar na prática do profissional, um caráter contraditório, não linear, possibilitando que os mesmos pudessem mediar conflitos e correlacionar forças antagônicas no interior das instituições e, com isto, construir estratégias de legitimação e reconhecimento da profissão de Serviço Social. (SOUZA, 2004: 109-110).

Dentro deste contexto é possível situar a funcionalidade que profissões da área humanosocial, diga-se o Serviço Social, veio assumido na esfera do judiciário, na medida em que disponibiliza o seu conhecimento teórico-metodológico, ético político, e técnico-operativo, utilizando-se dos relatórios e pareceres sociais como principais instrumentos de trabalho para subsidiar e acompanhar as decisões dos magistrados. Um exemplo deste trabalho é o acompanhamento, a execução e a fiscalização realizados pela CEPEMA, do Tribunal de Justiça do Distrito Federal e Territórios - TJDFT.

Assim, faz-se necessário discorrer sobre a organização judiciária do Distrito Federal, por ser este o lócus da pesquisa pretendida, sendo focalizada no TJDFT, mais especificamente na CEPEMA.

O TJDFT é um órgão da justiça comum brasileira ao qual compete processar e julgar os conflitos de natureza cível, criminal e [infracional]. (OLIVEIRA, 2005: 62 com adaptações).

É na primeira instância que se localiza a Vara de Execuções Criminais - VEC ${ }^{27}$ que tem como atribuição básica a execução, fiscalização e acompanhamento das penas privativas de liberdade, restritivas de direito e medida de segurança ${ }^{28}$. Todas resultados de sentenças provenientes das varas criminais de origem, ou seja, das diversas varas criminais ou juizados especiais dispostos em todo o Distrito Federal.

Dentro das atribuições da Vara de Execuções Criminais estão o acompanhamento e a fiscalização das penas restritivas de direitos ${ }^{29}$ que, em Brasília, seguindo a tendência nacional,

\footnotetext{
${ }^{27}$ Prevista no Código Penal e na Lei 7.210 de 1984 (Lei de Execuções Penais - LEP).

28 A pena privativa de liberdade é a restrição ao bem jurídico - liberdade de locomoção. Divide-se em duas formas: reclusão e detenção. A reclusão pode ser cumprida em regime fechado, ou semi-aberto, ou aberto. Já a detenção deve ser cumprida em regime semi-aberto ou aberto. A reclusão diferencia-se da detenção também com relação ao estabelecimento penal de execução. (JESUS, 2003: 523).

A pena restritiva de direito ver nota de roda pé número 30.

A medida de segurança possui caráter essencialmente preventivo e assistencial, no sentido de evitar que um sujeito que praticou o crime e se mostra perigoso venha a cometer novas infrações penais. São pressupostos da medida de segurança: a prática pelo agente (inimputável ou semi-imputável) de fato previsto como crime e a periculosidade. A aplicação desta medida é feita através de internação em hospital de custódia e tratamento e a sujeição a tratamento ambulatorial. (MIRABETE, 2004: 735)

${ }_{29}$ As penas restritivas de direito foram criadas como substitutivos penais à pena privativa de liberdade por estas não conseguirem atender aos objetivos de ressocialização, mas sim de dessocialização através do encarceramento. Foi através da Lei 7.209/84 que previu a possibilidade de se substituir a pena privativa de liberdade por pena restritiva de direitos: prestação de serviços à comunidade; interdição temporária de direitos e limitação de fim de semana; e pena de multa. A lei 9.714/98 acrescentou-se as penas de prestação pecuniária e perda de bens e
} 
criou em $2001^{30}$, a Central de Coordenação da Execução das Penas e Medidas Alternativas do Distrito Federal - CEPEMA, que possui um juiz substituto ${ }^{31}$ da execução que detém a função de execução, fiscalização e acompanhamento do cumprimento das penas restritivas de direitos, da suspensão condicional da pena e do regime aberto com prisão domiciliar ${ }^{32}$.

No mesmo ano, foi estabelecida a criação da Assessoria Psicossocial com função de assessoramento ao Juiz Coordenador da Central nas decisões quanto o julgamento, execução, acompanhamento, fiscalização e extinção do cumprimento das penas restritivas de direitos.

Diante desta estrutura organizacional, é possível inferir o grande número de mediações possíveis para se atingir a sua finalidade que é a prestação jurisdicional, para a promoção do controle social. E é também dentro desta complexa estrutura hierárquica que o Serviço Social alcançou seu espaço profisssional.

Neste ínterim, Faleiros (2001: 61) coloca que para manter a ordem e o controle político institucional, o profissional submete-se às normas institucionais, de onde se cria hierarquia de subordinação e poder numa rede de controle de cima para baixo. Para o autor (Ibidem: 62), esta subordinação se dá entre agentes privilegiados e agentes complementares. Os primeiros são aqueles que por sua prática vão legitimar a existência da instituição. Já os segundos são profissionais que têm de se submeter às práticas dos agentes privilegiados.

Ora, sabe-se que dentro do Judiciário a profissão que detém maior poder e reconhecimento é a magistratura, ou seja, o magistrado é visto e tido como um agente privilegiado, por mais que o considere dentro da trilogia jurídica (advogado - juiz - promotor). (GRINOVER, 2002: 294). O Juiz é visto de forma peculiar, pois é somente a ele que compete efetivamente prestar a tutela jurisdicional do Estado.

valores, transformando a prestação de serviços a comunidade em prestação de serviços a comunidade ou a entidades públicas, incluindo ainda, a pena de proibição de freqüentar determinados lugares entre as penas de interdição temporária de direitos (MIRABETE, 2004: 601-602).

30 A CEPEMA foi criada, na estrutura do Tribunal de Justiça do Distrito Federal e Territórios, sendo institucionalmente subordinada à Presidência do Tribunal de Justiça do Distrito Federal e Territórios, pela portaria de $\mathrm{n}^{\mathrm{o}} 15$ de 03 de maio de 2001.

${ }^{31}$ A CEPEMA é uma central e não uma vara, por isto possui juiz substituto, exercendo este o cargo dentro da central por um período não superior a dois anos.

${ }^{32}$ Suspensão condicional da pena é um benefício que permite não se executar a pena privativa de liberdade aplicada quando o condenado preenche determinados requisitos e se submete às condições estabelecidas na lei e pelo juiz (MIRABETE, 2004: 623).

A prisão domiciliar é destinada ao condenado que esteja em uma das situações estabelecidas no artigo 117 da Lei $\mathrm{n}^{\circ}$ 7.210, de 11 de julho de 1984, que são: I) condenado maior de setenta anos; II) condenado acometido de doença grave; III) condenada com filho menor ou deficiênte físico ou mental e IV) condenada gestante. 
Nesse sentido, o Juiz não é somente um mero funcionário do Estado, mas um dos agentes responsáveis pela institucionalização democrática do Estado de Direito. É ele quem exerce, como nenhuma outra autoridade pública, a capacidade de nivelar as partes que compõem um litígio, com a devida e proporcional igualdade de condições. E, para esta função, consideram-se como necessários pré-requisitos eminentemente técnicos, diretamente relacionados ao conhecimento jurídico. Saber este intitulado como dominante perante os outros saberes que também compõe o poder judiciário.

Pensando no Judiciário como espaço institucional que prepondera o desnivelamento dos saberes, a partir do poder instituído aos magistrados, Sbabo (2005: 55) coloca que no Judiciário constata-se diferenças entre um magistrado, um advogado, um administrador, um médico, um psicólogo, ou um assistente social, por mais que sejam todos trabalhadores, existe uma diferença de saberes, de status de poder entre as profissões. Cada uma é reconhecida pela sua prática, pela sua capacidade de atender a determinadas demandas, pelo conhecimento que domina e o prestígio que granjeou.

Entretanto, apesar do magistrado ser o detentor de um saber e conseqüentemente de um poder, isto não lhe garante o domínio sobre todas as áreas do conhecimento e, para obter uma proximidade maior com "questões sociais", e com questões psicológicas, ele necessita do auxílio de outras profissões, para assim aplicar com justiça seu poder jurisdicional.

Cabe aqui destacar a participação dos agentes complementares. Faleiros (2001: 62) coloca que certas profissões possuem o estigma de profissões complementares, dentre elas o Serviço Social, por não ter uma instituição específica para ele, atuando assim na ordem institucional determinada pelos agentes privilegiados.

E é neste aparente embate acima disposto que se situa a fonte de uma relação ainda maior que é a relação de poder entre profissionais, pois o poder dialoga diretamente com o saber e, como bem lembra o autor (2001: 10) "saber e poder são meio e fim que se articulam em cada conjuntura: saber para poder e poder para saber”.

O assistente social tem sua competência regida tanto pelo Código de Ética que prima a promoção e o acesso aos direitos dos sujeitos por ele atendido, como também pelo regimento interno da instituição (no caso o Tribunal), que define seu papel de assessor qualificado para subsidiar a resolução de determinadas demandas e tem, por sua competência profissional o poder de sugestão. (SOUZA, 2004).

Neste ponto, cabe destacar que mesmo sendo considerado um profissional complementar, ou até mesmo auxiliar da justiça, o assistente social detém competência 
legitimada formalmente para exercer seu poder, garantido pela lei de regulamentação profissional do assistente social ${ }^{33}$.

No âmbito Judiciário, o poder do assistente social, como foi assinalado, é o de sugestão. Contudo, não se restringe somente a esta função, pois o profissional por mais que esteja imerso em um ambiente complexo e hierarquizado, deve realizar ações direcionadas com base no compromisso com as ampliações de garantias de direitos, exercitando sua liberdade e criatividade. Deve estar atento às demandas institucionais e às demandas de seus usuários que vão além da relação instituição/usuário.

O profissional de Serviço Social detém um grande poder em suas mãos, ele pode intervir em diferentes situações, formando com o seu saber, com a compreensão da realidade e com a sua construção da verdade um suporte para promover mudanças dentro e fora de qualquer instituição, no caso em destaque o judiciário do Distrito Federal.

Importante destacar que para expressar este saber o profissional faz jus de instrumentos de poder perceptíveis utilizados na comunicação escrita - relatório e pareceres sociais.

\subsection{Saber e verdade em Serviço Social: ciência ou disciplina?}

Retomando o estudo realizado nos capítulos anteriores, verificou-se que o conhecimento científico adquiriu status de reconhecimento por lhe ser atribuído a característica de instrumento ideal para a construção da verdade, sobre a realidade humano e social. Assim, dentro do paradigma moderno de ciência, para ser considerado como ciência pressupõe-se ter objeto, teoria e metodologia próprios.

Neste sentido, o Serviço Social ao longo de sua trajetória profissional, deparou-se com o conceito de conhecimento científico e formulou posicionamentos distintos sobre a mesma temática. Como foi visto anteriormente, alguns autores defendem a viabilidade da produção científica do Serviço Social, posicionamento este minoritário. Já o posicionamento majoritário defende que o Serviço Social não constitui uma ciência social, mas sim sua derivação, na forma de disciplina criada sob o crivo da criticidade e do conhecimento empírico.

Considerar o Serviço Social como disciplina científica é colocá-lo em um patamar de conhecimento mais elevado, que não parte do senso comum, subjetivismos, preconceitos,

\footnotetext{
${ }^{33}$ Lei 8.662 de 07 de junho de 1993.
} 
hábitos, mas que também não o coloca como ciência em si. E sim, como um conhecimento que se baseia em teorias das ciências sociais.

Neste contexto, não há como negar a grande polêmica que permeou e ainda permeia o posicionamento dos assistentes sociais, como foi verificada nos discursos das entrevistadas, o que já fora visto com os autores do Serviço Social, ou seja, não há um entendimento unívoco ao considerar o Serviço Social uma disciplina científica, ainda que haja quem julgue este tema superado. No entanto, não há um entendimento harmônico entre os autores e até entre os profissionais.

Neste sentido, uma das entrevistadas colocou que o Serviço Social não obedece aos critérios estabelecidos para que um conhecimento seja considerado como ciência:

"acho que é uma disciplina cientifica porque assim, eu acho que não obedece, dentro do que a ciência coloca, do que você tem que ter, para você provar e tal, não sei se cai nos mesmos critérios do que eles estabelecem como ciência."(E4).

Observa-se que a definição do Serviço Social ser ciência ou disciplina científica vem principiada por uma dúvida, demonstrada em quase todas as entrevistas. Refletindo a incerteza no discurso das entrevistadas, visto o posicionamento indeciso e inseguro.

"É uma disciplina cientifica porque eu acho que já estabeleceu um determinado saber assim, específico para o Serviço Social que nenhuma outra área vai estar abarcando e que pode estar caracterizando ele como uma disciplina". (E3).

Desta forma, pode se observar que mesmo sem uma definição certa a respeito do tema as assistentes sociais classificaram o Serviço Social como uma disciplina científica, ou até mesmo, uma área de conhecimento que se enquadra dentro de critérios científicos:

"ah disciplina cientifica mesmo, não sei..., porque a gente faz um estudo da realidade das pessoas, da realidade social, das relações sociais e intervém em si, então eu acho que é uma disciplina cientifica”. (E1).

“... eu vejo como uma área do conhecimento e que muito mais se aproxima de ciência, não vou dizer ciência aqui no sentido lato da palavra, né, mas eu acho que a gente tem que ter um caráter de um conhecimento (...) a gente lida com o conhecimento, a gente se baseia em um conhecimento, a gente tem uma teoria que fundamenta, a gente tem todos os critérios estabelecidos aí para que se utilizando e se apropriando das áreas de conhecimento da sociologia, da economia, da filosofia e de todo ramo de conhecimento que diz respeito às ciências sociais ou ciências humanas..." (E1). 
Mesmo assim, o ponto comum no discurso das assistentes sociais parte do pressuposto de que o Serviço Social apreende a realidade social dos usuários a partir de perspectivas teóricas, metodológicas reconhecidamente científicas e, portanto, distanciadas do senso comum, o que, por si, já atribui cientificidade ao seu saber e fazer profissional.

Destaque-se que o Serviço Social não é uma área do conhecimento que possui um objeto, metodologia e teorias próprios, mas constrói o seu saber a partir do conjunto de conhecimentos que leva em consideração "a dinâmica da história, a historicidade dos processos, a especificidade e a dinâmica de cada conjuntura" (FALEIROS, 2005: 69). Desta forma, não se pode reduzir a produção do conhecimento no Serviço Social a um único objeto de intervenção.

Frise-se que duas das assistentes sociais ressaltaram que a especificidade do Serviço Social talvez esteja na multiplicidade de conhecimentos das outras áreas do conhecimento humano social:

“...Eu acho que tem uma mistura né, eu vejo na sociologia, na filosofia, na antropologia, a gente vai lá buscar informações disso daí, de cada uma..., na minha formação estudei, introdução a sociologia, a filosofia, quer dizer eu acho que a gente vai normalmente se apropriar de conhecimentos, que não são ditos específicos dentro do Serviço Social, mas a gente vai buscar este conhecimento,de toda e qualquer forma que você vai buscar nos outros ramos do conhecimento, né..."(E3)

"é a Questão Social, né, e suas várias facetas, embora isso possa estar parecendo uma sociologia ou antropologia, mas não da maneira tão assim, no caso o Serviço Social é bem mais voltado para essas questões, né, e inclui múltiplas manifestações que aí vai estar relacionado com todas as políticas sociais de uma maneira que nenhuma outra área do saber vai estar lidando". (E4).

Outro ponto polêmico expresso no discurso das assistentes sociais diz respeito à relação entre "ser ciência" e "ter objeto específico". Neste ponto, as profissionais colocaram que o Serviço Social se define através de sua especialização, que tem como base a Questão Social, tal como Iamamoto dispõe (2005: 27) que "a especialização do trabalho do assistente social tem sua base de fundação na Questão Social, considerada como o conjunto das expressões da desigualdade da sociedade capitalista”. O assistente social trabalha com as várias expressões que assumem as desigualdades, conforme fala das entrevistadas:

"O Serviço Social trabalha com a questão social, com o humano, acho que o objeto é esse, a questão Social”. (E2). 
"O objeto do Serviço Social é a atuação junto a Questão Social, é o que define sua especificidade". (E5).

"Eu acho que é um serviço especializado. Como uma área do saber que vai estar sabendo como fazer, através do que eu acho que é seu objetivo, estar viabilizando o direito dos usuários, aceitando essas políticas visando o direito daquela pessoa e acho que ela é uma especialização sim, sei que outras disciplinas, outra profissão não poderia estar fazendo da maneira como o Serviço Social faz”. (E4).

Entretanto, pode-se constatar, novamente, a confusão e contradição em torno da cientificidade e especificidade do Serviço Social, pois ao dizerem que a profissão não é uma ciência estariam afirmando implicitamente que não há um objeto específico para esta profissão como colocaram ser a Questão Social. Outro destaque de incoerência é a apropriação deste tema como específico do Serviço Social, como se outras profissões não trabalhassem diretamente com a Questão Social ou não viabilizassem direitos, também.

Quando se fala em especialização se fala em um profissional que possui uma forma particular de explicar e compreender a realidade, e para definir ou decifrar esta peculiaridade, parte-se de um referencial teórico-metodológico. Este referencial será sua orientação, “um caminho do pensamento" (E5) que impede que seja apenas um mero trabalho mecânico e acrítico, ou seja, será o resultado de toda uma produção histórica de conhecimento.

Por outro lado, a própria complexidade em que se insere a realidade social, substrato básico do trabalho do assistente social, pressupõe o reconhecimento do pluralismo teóricometodológico necessário para compreender a totalidade social, bem como, para aprender e explicar, na sua particularidade e singularidade, a realidade cotidiana dos seus usuários.

A maioria das assistentes sociais da CEPEMA identificou o referencial dialéticomarxista como aquele que subsidia a compreensão e explicação da realidade social dos usuários, expressa nos relatórios e pareceres realizados.

Percebeu-se também que as particularidades que envolvem os diferentes espaços ocupacionais exigem que o assistente social disponha de conhecimentos teórico-metodológicos inerentes aos agentes privilegiados da instituição.

Um reflexo disso está na fala das assistentes sociais da CEPEMA ao destacarem a exigência de saberes que vão para além da sua formação.

“...a gente constrói um conhecimento sobre esta realidade, uma compreensão, né, então assim, o conhecimento para a gente dar conta destas realidades é muito amplo, agora eu acho que a gente tem que dá conta na compreensão do que é o nosso fazer profissional...". (E3). 
“... Eu acho que pra gente lidar na justiça a gente acabou tendo que aprender um pouquinho de Direito, conhecer o Código Penal, conhecer a Lei de Execução Penal porque se você não tinha um mínimo de conhecimento nesta área você não tem nem como propor alguma coisa nos processos...". (E1).

“... aqui a gente tem que ter o valor jurídico também. São as leis né...”. (E2).

Ora, dentro da relação de emprego que se vive hoje, o profissional tem que ser polivalente, detendo conhecimento das diversas áreas, sem perder de vista o enfoque na sua formação profissional, em detrimento das exigências da instituição.

Sendo assim, o conhecimento jurídico torna-se, juntamente com outros, um dos principais meios de trabalho do assistente social da CEPEMA para a construção de saberes e verdades sobre a realidade social dos usuários, saberes e verdades que, muitas vezes, se colocam como desafio na busca de uma suposta especificidade dentre as outras áreas do conhecimento humano-social como a Psicologia, a Pedagogia e o Direito.

Para além das questões epistemológicas que envolvem a discussão da cientificidade e especificidade do Serviço Social, principalmente no meio acadêmico, não se pode desconsiderar que, no âmbito institucional, esta discussão traz angústia e insegurança nos "profissionais da prática", por exigir do profissional uma capacidade de pensar e refletir sobre a própria condição de especialista e, portanto, conhecedor da realidade humano-social, vista e interpretada dentro de critérios científicos. Da mesma forma, exige-se do profissional a capacidade e competência para relacionar dialeticamente os três pilares básicos da profissão: conhecimento teórico, competência técnica e compromisso ético.

Destaca-se o papel que os Pareceres e Relatórios Sociais têm desempenhado no trabalho do assistente social da CEPEMA e a sua contribuição na construção de espaços de saber e poder na instituição.

\subsection{Parecer, Laudo e/ou Relatório Social.}

Não obstante ser identificado, muitas vezes, como um mero instrumento de trabalho do assistente social, não se deve esquecer que os instrumentos técnico-operativos, inclusive os Relatórios e Pareceres, não devem ser vistos como um fim em si mesmo, mas como um meio imprescindível para e da articulação entre o teórico e o ético, que, juntos, expressam a instrumentalidade da profissão. 
Trazendo para a análise das entrevistas, com relação ao instrumental técnico-operativo utilizado pelas assistentes sociais, foi questionado qual era o seu entendimento sobre o assunto, e as respostas dirigiram-se por uma vertente mais tradicional, de forma mais genérica, limitando-se ao conjunto de instrumentos e técnicas utilizados para a consecução de suas finalidades, como exemplos destacam-se: "São os instrumentos que a gente utiliza para trabalhar". (E2). "São todos os instrumentais que a gente adota". (E4). "São os instrumentos que a gente utiliza no dia-a-dia, na rotina de trabalho". (E1).

No entanto, houve uma entrevistada que abarcou o instrumental de forma completa, não compreendendo somente um arsenal de instrumentos e técnicas, ou seja, só a instrumentação, mas abarcou também os conhecimentos e habilidades como instrumentos utilizados para o alcance de seus objetivos:

"É o conjunto articulados de instrumentos e técnicas, mas que vão além das técnicas, é muito mais que isto, é também os conhecimentos e habilidades. Um instrumento por si só não é um fim em sim mesmo, deve estar sempre relacionando com o compromisso profissional e os princípios ético-politicos, teórico-metodológico e ético-político". (E5).

O instrumental não é composto apenas do agir, ou melhor, da prática, mas abarca também as teorias e as formas de compreender a realidade. A prática profissional não pode ser apreendida apenas a partir da aplicação de instrumentos técnicos. A prática mais elaborada levará em conta estes instrumentos, mas a partir de um aporte teórico que fundamente a utilização e os resultados da aplicação dos instrumentais. Portanto, compreende todos os elementos que compõe a intervenção profissional. É a partir desta prática mais elaborada que o profissional estabelecerá quais instrumentos estarão mais adequados à sua realidade de trabalho.

Deste modo, ao aprofundar o estudo sobre os instrumentos utilizados na comunicação escrita do assistente social (Parecer, Laudo e Relatório Social) verificou-se não existir um consenso a respeito das terminologias teóricas e técnicas, sobre este tema, pois os posicionamentos dos principais autores que trabalham esta temática baseiam-se em conceitos muito amplos e similares uns dos outros, o que acaba por criar confusão e imprecisão conceitual.

E, para confirmar esta afirmativa, toma-se como exemplo o conceito de Relatório, onde segundo Magalhães, do ponto de vista léxico, (2003: 60) é a descrição ou o relato do que foi possível conhecer por meio do estudo, ou seja, um parecer ou uma exposição dos fundamentos 
de uma apreciação, ou ainda, qualquer exposição pormenorizada de circunstâncias, fatos e objetos. Segundo a autora os relatórios podem ser referentes a uma pesquisa, à comunicação das atividades desenvolvidas, ou até mesmo conter informações que subsidiem a tomada de conhecimento sobre determinado caso. (2003: 61).

Já Fávero (2003: 44-45) assevera que o Relatório se traduz na apresentação descritiva e interpretativa de uma situação ou expressão da Questão Social e deve apresentar o objeto de estudo, os sujeitos envolvidos e finalidade à qual se destina, os procedimentos utilizados, um breve histórico, desenvolvimento e análise da situação.

Sendo assim, o relatório é a descrição e análise dos fatos, dados e resultados de atividades diversas.

Já o Parecer Social, de acordo com Fávero (2003:19-20), é o posicionamento do profissional perante determinada realidade. A origem deste instrumento se deu com a finalidade de subsidiar as decisões e ações que tramitavam na esfera da justiça "restabelecendo a verdade dos fatos ${ }^{34}$, ou a construção de provas a respeito da ação em litígio ou em exame".

Segundo alguns autores (FÁVERO, 2003 e 2005; MIOTO, 2001), o Parecer é uma peça fundamental para a construção de um instrumento ainda mais complexo que é o laudo social. Ou seja, o parecer é uma das etapas do laudo social, diga-se a etapa final. No entanto, cabe ressaltar que o parecer pode ser uma peça avulsa, sem precisar necessariamente estar vinculado ao laudo social.

Para situar, de acordo com os autores, onde geralmente fica o parecer, necessário se faz compor a estrutura básica, mas não rígida, do laudo social, para assim chegar ao parecer social. Sendo assim, o profissional deve estar atento primeiramente quanto a quem o demandou, se foi por via judicial, demanda sinalizada pelo profissional, ou se foi demanda espontânea do indivíduo. Posteriormente, o profissional deve realizar uma breve identificação dos sujeitos envolvidos, definir qual metodologia irá utilizar para construir o parecer (dispondo do instrumental utilizado, dos objetivos do estudo) e fazer um relato analítico da construção histórica da questão estudada e do estado presente da situação. O relato analítico é o ponto mais importante, pois é ele que dará todo o suporte para se fundamentar a decisão de um

\footnotetext{
${ }^{34}$ Ao se falar em "verdade" na esfera das profissões que compõem as ciências sociais e humanas, onde se destaca o Serviço Social, o conhecimento adquirido acerca da trajetória de vida pessoal e social dos usuários da justiça está circunscrito inerentemente a uma realidade essencialmente humano-social (que é histórica, dinâmica, complexa, heterogênea e multifacetada). Portanto, não pode ser apreendido dentro dos critérios de objetividade e neutralidade que caracterizam o direito positivista brasileiro, o que implica, do ponto de vista do trabalho do assistente social, não trabalhar com verdades absolutas, estáticas e a-históricas (SOUZA, 2006: 03).
} 
parecer - por fim, a conclusão ou parecer social, que expressará uma breve análise crítica, apontando para possíveis alternativas ao caso, e concluindo com o ponto de vista do profissional frente à questão do estudo (FÁVERO, 2003: 46, com adaptações).

O Parecer Social é tido como um documento fundamentado e resumido sobre uma questão focal, que esteja ligada à questão social, ou seja, é o esclarecimento e análise com base no conhecimento específico do Serviço Social (com referência aos seus fundamentos teóricos, éticos e técnicos), com um estudo rigoroso e fundamentado, visando dirimir dúvidas e esclarecimentos que estão interferindo na decisão do magistrado, ou que o profissional tenha sinalizado e que necessite de sua intervenção, de caráter indicativo ou conclusivo.

Assim, comparando o Relatório e o Parecer, verifica-se que as suas funções em alguns pontos embaralham-se por serem todos instrumentos de comunicação com os atores privilegiados, comunicação esta tanto descritiva, avaliativa quanto opinativa. Desta forma, cada intelectual e profissional que lida diretamente com estes instrumentais possuem ampla liberdade na produção dos mesmos, resultando com isto dificuldades em distingui-los.

Nas entrevistas ficou claro que as profissionais utilizavam o relatório como instrumento da comunicação escrita. No entanto, ao argüir sobre o percurso metodológico utilizado, ficou claro que algumas produziam o relatório com características de Parecer Social, contendo ao final alternativa(s) e o posicionamento do profissional, como foi visto acima. Desta forma, após conhecer o percurso metodológico, procurou-se aprofundar esta temática, perguntando às assistentes sociais qual era a diferença entre Relatório e Parecer Social, sendo obtidas respostas diversas.

Uma parte das entrevistadas entende que o Parecer Social está contido no relatório:

\footnotetext{
"Bom, no relatório você vai estar escrevendo toda aquela situação que foi identificada, no caso seria a perícia, (...) e por último né, você vai estar concluindo e dando um parecer que é a sua análise e uma sugestão né, uma alternativa se tiver alguma coisa para propor né, uma sugestão. O parecer é parte do Relatório, para mim um relatório são duas partes. Primeiro tem, a descrição da situação e tudo que você investigou né, e por último tem a parte conclusiva do Relatório que é o Parecer. O Parecer é a conclusão, é uma análise daquilo que foi periciado e pode ter uma sugestão”. (E2).

"O relatório é um instrumento específico do Serviço Social, é também lugar que se faz análise da situação. Nem sempre o relatório dá um posicionamento indicativo ou conclusivo. $O$ relatório é um documento de análise e interpretação de uma determinada situação. Já o parecer pode estar contido em um relatório da pesquisa e estar contido em um laudo social. Parecer é uma manifestação sobre determinada situação, sobre a realidade, emissão de uma situação”. (E5).
} 
Outra entende que Relatório Social e Parecer Social são documentos distintos, contudo a característica de sugestão pode estar contida em um relatório. Destaca-se nesta fala a justificativa de se produzir mais Relatórios Sociais que Pareceres Sociais devido à grande demanda de trabalho que dificulta a produção de documentos mais elaborados e fundamentados.

"O relatório você tem de tudo aí, as coisas mais simples que podem ter num relatório: informar o final de pena, um descumprimento ou como é que está a situação da pessoa ah. Agora, quando vem um parecer é diferente porque o juiz quer que você se posicione e geralmente isso depende de quê? De um estudo. (...) você vai ter que fazer um relato, no final você vai se posicionar, fazer sugestões de acordo com as considerações levantadas. Então Parecer exige um estudo né e um posicionamento do técnico. Pode ser também que no relatório a gente tenha que fazer sugestões também, mas o que tem no relatório é que não necessariamente tem que ter uma coisa tão aprofundada como o Parecer (...) depende muito do caso quando é pedido pelo juiz, que a gente faz né, sugere tal e a gente faz ainda muito menos porque eu acho que é muito rico, mas pela demanda de trabalho da seção a gente faz muito menos do que deveria fazer". (E4).

Na CEPEMA o instrumento mais utilizado é o relatório, e utiliza parecer mais para os técnico que acompanham na área de saúde."(E1).

Uma entrevistada afirma que os posicionamentos dos autores e profissionais que trabalham com pareceres e relatórios sociais não são uno, e que para ela ambos seriam uma construção de um conhecimento sobre a realidade:

"O relatório, vai registrar aí a construção daquele conhecimento sobre aquela realidade, seria assim onde você vai dar as suas conclusões finais e sugerir, né, mas eu não sei se é isto não (...) Mas eu entendo assim, o relatório é um estudo social, você constrói um entendimento sobre aquela realidade. Eu acho que tanto no parecer quanto no relatório você não vai sugerir do nada. (...) é uma construção de um conhecimento sobre uma realidade e pra isto você tem que construir realmente como na ciência construir um conhecimento, né sobre aquela realidade e a partir dai você vai se posicionar, eu acho que é isso". (E4).

Como foi visto cabe a cada profissional definir sua compreensão sobre seu instrumental. Alguns utilizam o relatório e o parecer conjugados, e outros já possuem entendimento de separação, o que não pode perder de vista é que tanto o Parecer Social quanto o Relatório Social não são instrumentos exclusivos do profissional de Serviço Social e o que vai diferenciar estes dos relatórios e pareceres de outros profissionais é a sua compreensão da realidade e sua concepção de verdade, com base nos seus próprios fundamentos teóricometodológicos, ético-políticos, técnico-instrumental. 
Deste modo, cabe destacar que a produção dos Relatórios e Pareceres realizados pelas assistentes sociais da CEPEMA prescinde da realização de outros instrumentos de trabalho. Dentro do percurso metodológico, o estudo social é o caminho ou a direção para a utilização dos outros instrumentos como: a entrevista ${ }^{35}$, visitação ${ }^{36}$ (domiciliar, institucional), consulta aos autos, observação, bagagem teórica ${ }^{37}$ (conhecimento), além do Estudo social ${ }^{38}$. Na tabela 01 (em anexo) foram listados os instrumentais técnico-operativos, respondidos pelas as entrevistadas, onde as entrevistas e os relatórios foram os dois instrumentais mais citados.

Em toda a fase do acompanhamento de uma pena alternativa, as entrevistas com os usuários (prestadores de serviços à comunidade) são utilizadas em grande escala por todas as profissionais.

O segundo instrumental mais citado pelas entrevistadas foi o relatório que é um dos instrumentos mais utilizados pelo profissional no âmbito do judiciário, considerado como um dos instrumentos que dá uma maior representação material ao seu trabalho, pois é este documento que faz prova do poder do assistente social, expondo e materializando toda a intervenção do profissional e que de alguma forma intervirá na trajetória do usuário.

Com relação às demandas, os motivos que mais geram relatórios, segundo as entrevistadas, são: de cumprimento ou não da pena; conversão de pena; definição de valores da prestação pecuniária $^{39}$; impossibilidade de cumprimento da pena por causa de horário de trabalho; suspensão da pena por motivo de saúde ou uma internação; fim de pena;

\footnotetext{
${ }^{35}$ A entrevista é utilizada para obter dados do(s) usuário(s). É um instrumento importante e fundamental para entendimento das situações na sua complexidade, garantindo que o entrevistado esteja em condições favoráveis para participarem do atendimento (JESUS, 2004: 65). Para isto, a postura atenta do profissional é indispensável para o sucesso da entrevista, fazendo uso da linguagem adequada, conter qualquer tipo de manifestação preconceituosa, observar o que a pessoa diz, e principalmente o que ela não diz, ser cordial com o entrevistado, por fim, manter uma atitude profissional frente ao entrevistado.

${ }^{36}$ A visita tem como objetivo proporcionar maior entendimento de um caso em sua particularidade dentro do contexto das relações sociais que o indivíduo ou a família vivenciam cotidianamente encontrem.

${ }^{37}$ O conhecimento é classificado como parte do instrumental técnico-operativo, pois permite que não haja um distanciamento entre a teoria e a prática, além de garantir a análise e a interpretação da realidade, bem como uma atuação coerente e comprometida para a consecução do projeto ético-político da profissão.

${ }^{38}$ O Estudo social é utilizado pelo assistente social para orientar o seu trabalho, tanto no planejamento de intervenções como para demonstrar a situação sobre uma realidade investigada ou trabalhada, proporcionando-lhe respostas às necessidades da atuação profissional.

${ }^{39}$ A prestação pecuniária consiste no pagamento em dinheiro à vítima, a seus dependentes ou a entidade publica ou privada com destinação social, de importância fixada pelo juiz, não inferior a um salário mínimo nem superior a trezentos e sessenta salários mínimos. Art $45 \S$ do Código Penal Brasileiro.
} 
encaminhamento para as escolas, para creches, para Centro de Referência de Assistência Social, para abrigos.

Segundo uma entrevistada, cabe somente ao assistente social saber se a demanda exige ou não a produção de um relatório:

"O relatório é feito quando o profissional sente que a situação vai interferir no processo, isto, em resposta ao juiz. Compete somente ao profissional saber quando será feito o relatório" (E5).

Com isto percebe-se que o conteúdo e os objetivos dos relatórios são os mais variados e que para fazê-los, deve-se traçar um percurso metodológico, que segundo as entrevistadas não segue um padrão podendo ser elaborado de diferentes maneiras, dependendo das possibilidades de acompanhamento do usuário. Dessa forma, não há que se falar em um único percurso metodológico, mas em vários percursos. Alguns dos percursos metodológicos mais citados e que não seguem a ordem disposta são:

(1) Conhecer a realidade, à luz da compreensão que se tem daquela realidade, com base no compromisso ético político.

(2) Identificar junto à pessoa (usuário) o motivo pelo qual está ensejando o relatório, se é por descumprimento, cumprimento irregular, impedimento de trabalhar, enfim, sinalizar o motivo real que está ensejando o relatório.

(3) Utilizar todos os instrumentos necessários da profissão para compreender a situação, que geralmente são: entrevistas, atendimentos individuais e familiares, contatos com as instituições de tratamento ou de prestação de serviços, visitas e encaminhamentos.

(4) Faz-se uma descrição da situação dos indivíduos, da situação processual seguida do detalhamento da situação de vida deles e por fim, criam-se sugestões e alternativas para aquele caso. Neste ponto, é importante destacar que as sugestões mais indicadas no relatório são: conversão de modalidade de restritiva de direito, se descumpriu apontar o motivo e se necessário indicar uma alternativa para que a pessoa cumpra sua pena, suspensão da pena, indulto humanitário, encaminhamentos diversos, mudança de local de cumprimento da pena e a possibilidade de até inovar nas sugestões desde que elas não contrariem a lei.

É claro que o relatório não conterá todas as informações colhidas durante o estudo social, nem tudo caberá colocar em um relatório, pois dependerá da situação concreta para a utilização dos instrumentos, fazendo uma articulação com a totalidade da situação, e não enfocando simplesmente o problema e subtraindo todos os seus fatores condicionantes. 
Caberá, neste momento de confecção do relatório, impor seu poder de saber sobre determinada realidade, dentro dos princípios ético políticos, decidindo utilizar o instrumental mais apropriado para a situação na busca pela garantia dos direitos humanos e sociais da população atendida.

\subsection{Os Relatórios como fonte de poder}

É principalmente no relatório que o assistente social consegue transpor seu poder e o seu saber, diante de determinada situação, na qual o juiz não tem conhecimento, ou não consegue solucionar, necessitando da atuação do profissional de Serviço Social competente.

Ressaltasse que o assistente social, ao trabalhar com estes instrumentos, deve ter a cautela de utilizá-los para ampliar e defender a cidadania, e não reduzir a um mero agente burocrático e tecnicista. O profissional tem nas mãos uma fonte de poder e deve utilizá-la de forma critica e racional, não para cumprir apenas determinações jurídico-legais e cumprimento de regras institucionais, tal como afirmam as entrevistadas:

\footnotetext{
"É essa compreensão que a gente tem da realidade, né, se você compreende dentro daquela relação (...) Você vai lá você dá conta desta realidade fundamentando-se, dentro do compromisso ético-político, e que você compreende dessa sociedade ai você vai para o conhecimento que ta fundamentando tudo. (...). O conteúdo teórico do relatório é o diferencial da profissão, sem ele não justificaria, né, porque não é o ato de fazer, (...) é a compreensão que a gente tem, e às vezes parece que os profissionais esquecem na prática esta compreensão e vai se deixando guiar pelo senso comum, porque chega num lugar, aqui no Tribunal de Justiça você tem que cumprir os objetivos institucionais, mas quais são os meus objetivos profissionais?" (E3)
}

Desta forma, o profissional da CEPEMA deve saber trabalhar com o conflito da demanda institucional (restrição de direitos) e a demanda profissional (garantia de direitos), e conciliar este impasse por meio de sua fundamentação, ou melhor, através do seu poder de sugestão refletido e materializado nos relatórios e pareceres, onde o profissional utiliza todo seu arcabouço teórico-metodológico, técnico-operativos e ético-político, sobre determinada demanda social podendo, assim, opinar, sugerir ou responder consulta ou determinação da autoridade judiciária. 
Quando se pergunta qual é a relação de poder entre o magistrado e o assistente social pergunta-se de uma forma geral, para situar qual o nível de percepção da relação entre o profissional e o magistrado, que inclui tanto a questão de aceitação do trabalho, quanto o reconhecimento deste trabalho. Com relação a esta pergunta, o resultado da pesquisa foi inesperado, as entrevistadas pautaram que o magistrado ao receber um relatório feito por uma assistente social acolhe em quase sua maioria as sugestões e propostas de alternativas contidas neste documento, isto porque existe uma "aceitação" do trabalho, se este estiver condizente com os limites e regras impostos pela instituição judiciária, ou seja, em concordância com a lei. Contudo, isto não reflete um reconhecimento do próprio saber do qual o assistente social detém, ou seja, um reconhecimento do saber produzido por este profissional.

Por outro lado, quando se fala em reconhecimento profissional, isto é, da competência do profissional, o magistrado muitas vezes reduz o papel do assistente social, seja pelo desconhecimento das competências e responsabilidades legitimadas pelo Serviço Social, seja por não se atentar à dinâmica da sociedade, que necessita de profissionais capacitados para estudar uma determinada realidade fora dos parâmetros legalistas. Surge então um duplo viés, ou melhor, uma contradição, que é submissa ao poder/saber dos magistrados sobre os outros profissionais auxiliares.

"Eu acho que o acolhimento tem sido sempre, porque você está pondo um conhecimento seu, fundamentando eu acho que a gente tem um poder muito grande, (...) a gente não parte de uma simples descrição, a gente parte de uma compreensão sociedade. Agora em outros sentidos a gente ainda sabe que pela questão da hierarquia porque você falar de uma profissão você esta falando também de uma relação de poder como está nesta divisão social do trabalho e a gente tem que dar novamente um olhar na sociedade e ver nesta relação de trabalho como se colocou as profissões que tem poder (...) no Judiciário o Juiz tem mais poder, nos diversos locais em que o poder da profissão se materializa relacionado ao tipo de instituição, que aqui é o juiz no hospital é o médico, não existe este reconhecimento do ponto de vista do poder, agora há um reconhecimento na hora de acatar, parece uma coisa complexa, são dois tipos de poder, reconhece e acata dentro de uma fundamentação teórica, de um conhecimento da realidade, mas aqui não há reconhecimento, pois se está falando de relação de poder" (E3)

"Não tem aquela igualdade. É uma desigualdade de poder, na relação de poder o juiz pode mais né, ainda mais no judiciário, aqui é mais aberto, é uma relação mais aberta apesar de na hora de mostrar poder, é um juiz né, é o poder dele que prevalece. A proporção de acolhimento dos relatórios depende da experiência profissional do juiz, se ele é um juiz inexperiente, que não conhece bem, que não conhece a prática, o nosso trabalho, é um juiz novo, inexperiente, ele não vai valorizar muito o trabalho, ele vai julgar, vai ver pelo lado que ele entende que é certo". (E2). 
Quando se intitula que determinado saber, no caso o jurídico, é o saber que detém a verdade, os demais saberes são desprezados, gera-se assim uma correlação de forças, tanto para se legitimar (jurídico), quanto para serem reconhecidas (Serviço Social). De acordo com Foucault (2003: 230), "existe um balizamento dos mecanismos de poder no interior dos próprios discursos científicos, a qual regra somos obrigados e coagidos a obedecer, em uma certa época".

Outro autor que estuda a correlação de poder/saber é Vicente Faleiros ao destacar que o processo de elaboração do saber chamado técnico e científico passa por condições de poder bastante rígidas e estabelecidas pelas instituições, onde nas relações de poder há dominantes e dominados, há um poder hegemônico que domina perante os outros.

"A ciência social desenvolve-se num conjunto de relações de saber e poder que refletem as lutas sociais e, portanto se situam em relações de dominação e subordinação. Sendo assim, um grupo poderá impor determinadas regras que podem passar a ser consideradas dominantes no momento determinado" (FALEIROS, 1993: $59)$.

Sendo assim duas entrevistadas fazem colocações a respeito do reconhecimento do saber jurídico sobre os demais saberes que trabalham na instituição, colocando estes saberes no patamar não de subsidiários, mas de submissão ao saber jurídico:

"a maioria do que a gente, sugere é acatado, na maioria das vezes eu acho que é difícil dele se colocar contrário. Eu posso dizer que na maioria dos casos é sempre favorável às sugestões do profissional dos assistentes sociais. Agora, claro que o nosso saber aqui não é colocado numa relação de igualdade com o Direito, a gente é um saber abaixo e assim, de uma maneira meio, subalterna, para resolver os problemas do juiz assim, (...) o problema dele é que as pessoas cumpram as penas. Aceitam o que a gente fala? Aceitam, mas assim, não vou dizer que reconhece o nosso trabalho, porque que a gente está aqui, só que falta muita coisa para caminhar para que eles percebam o nosso, claro que se está numa instituição muito autoritária, muitos juizes ainda tem essa visão de super valorizar o Direito, de que o que prepondera é aquilo e ponto final sabe, o outro está lá para me auxiliar. Eu vejo a coisa muito assim, (...) sempre fala que a Cepema não funciona sem a psicossocial, que é fundamental, mas o reconhecimento, está longe do que deveria ser". (E4).

"Eu acredito que a maioria dos magistrados acham que tem os funcionários da psicossocial para assessorá-lo e dá sugestões com relação ao cumprimento e acompanhamento da pena. Com relação a proporção de acolhimentos, é quase cem por cento. Por parte de alguns juízes eu acho que alguns tem a dificuldade de aceitar”. (E1).

A liberdade que o profissional detêm dentro de uma instituição é ditada tanto pelo seu Código de Ética quanto pelos regimentos internos da instituição, mas quem se respalda nos princípios ético-políticos sabe que o profissional detém uma autonomia e um poder em suas 
mãos para realizar escolhas, que visam primeiramente garantir e ampliar os direitos do usuário, e com isto interferindo positivamente em suas vidas.

"Hoje ele não sabe o papel do assistente social, onde equipara nossas atividades com a do cartório. $O$ assistente social tem que ter autonomia para trabalho é ele que pode assessorar com aquilo que ele tem competência para fazer. Liberdade para fazer escolhas, com respaldo no projeto ético-político da profissão. Quando se faz uma sugestão que tá dentro das normas da instituição, o juiz acolherá todos, não descumprindo os ritos da instituição. Quando se passa por questões mais profundas, então não é tão simples assim. Conflitos institucionais com os profissionais, não pode perder de vista com quem é seu compromisso, que é com o usuário”.(E5).

Com relação à mudança na trajetória processual e de vida dos sentenciados, a fala de uma entrevistada resume o que é, e como esta seria, visto do ponto da totalidade, e não como fato isolado:

Eu acho que muda num sentido que você tem que contextualizar o que é esta mudança, eu acho que quando você responde esta pergunta você tem que ter vários olhares, primeiro tem que conhecer a sociedade, compreender a situação concreta daquele sujeito pra depois você dizer que aquela pena mudou a vida dele, porque ela vai mudar a partir da ótica que você tá vendo, e ai, você tem que compreender o que você ta chamando de mudança.

É preciso salientar que o papel do assistente social ao sugerir alternativas à sentença do Juiz é fundamental para o cumprimento de uma pena condizente com as condições reais da sociedade, permitindo ao Serviço Social aproximar o Direito com a realidade do indivíduo cumpridor de sentença penal.

A ciência-jurídica prima pela busca da verdade que não é estática, mas dinâmica, complexa e multifacetada, com conteúdo relacional e temporal.

Diante disso, deve-se rever constantemente os conhecimentos, intertextualizá-los com outros conhecimentos e relacioná-los criticamente com a realidade que se faz presente na sociedade, considerando que o objeto é construído e não dado. A verdade não é unilateral, muito menos vertical, mas multilateral, rica e horizontal, onde todos os conhecimentos contribuem para um processo de conhecimento construído por todos. 


\section{CONSIDERAÇÕES FINAIS}

A partir do presente trabalho, almejou-se aprofundar o estudo do Parecer Social como instrumento de poder elaborado pelos assistentes sociais. Pôde ser constatado que o saber detém um status de reconhecimento quando é tido como fonte de verdade. E, o que as ciências tentaram ao longo da história angariar o poder de dizer a verdade, prevalecendo sobre as outras formas de conhecimento. Diante disso, o Serviço Social também sofreu a influência desta cientificação do conhecimento em busca deste status de reconhecimento e legitimidade.

Percebeu-se que a discussão a respeito da cientificidade do Serviço Social não se resta superada, sendo percebida tanto através do posicionamento de autores renomados da profissão, como também através do discurso dos assistentes sociais entrevistados, que não definiram ser o Serviço Social ciência, mas também, não definiram com confiança como se classificaria o conhecimento utilizado pelo Serviço Social. Percebeu-se que este impasse reflete diretamente na forma como a profissão é reconhecida dentro e fora do âmbito acadêmico.

Neste sentido, ao analisar como se deu a evolução do Serviço Social como profissão técnica e teórica, quis-se demonstrar como e quanto a profissão prosperou ao longo de sua história. Como se transpôs de uma atividade meramente caritativa e técnica para uma profissão estruturada teórica e metodologicamente, regulamentada, com princípios e atribuições privativas, tais como: realizar assessoria e consultoria a órgãos da administração pública, vistorias, laudos, relatórios, perícias e pareceres sobre a matéria de Serviço Social, dentre diversas outras atribuições que estão elencadas na lei 8.662 de 1993. E foi com base no Parecer Social que desenvolveu-se toda a pesquisa, por ser um dos instrumentos que materializa o trabalho do assistente social no âmbito da Justiça.

Até a realização deste estudo, considerava-se ser o Parecer Social o instrumento que melhor materializava o poder do profissional mais utilizado dentro do Judiciário, contudo o que verificou-se foi que esta consideração é relativa, por não existir uma definição padronizada sobre o documento, dependendo de qual posicionamento se tem a cerca do que é o Parecer Social. Quando se pensa o Parecer Social como um documento único, ou seja, um documento oficial, sua utilização dentro da Seção Psicossocial da CEPEMA é pouco solicitado e em conseqüência pouco produzido, no entanto, quando se considera o Parecer Social um segmento, ou seja, um posicionamento contido dentro de um documento, que pode ser tanto 
um relatório, um laudo, uma perícia, aí então veremos que o Parecer Social é consideravelmente aplicável na Seção.

O motivo de fazer esta distinção surgiu quando foi estudada a bibliografia acerca do tema e concluiu-se que não há um formato oficial de Parecer Social que disponha um estilo ou padrão para este documento. E não deve existir tal padronização, por ser o Parecer um documento realizado dentro da discricionariedade do profissional, podendo estar embutido dentro de um documento, ou formalizar um documento próprio, pois isto não interferirá a qualidade e o comprometimento que o assistente social tem e deve ter ao comunicar-se com o Magistrado.

Destarte, não se desconsidera o Parecer Social como o meio de comunicação entre assistente social e Juiz, o que se desconsidera é o formato em que foi produzido, pois se o profissional deter conhecimento e compromisso ético, ambos instrumentos profissionais, o assistente social não se perderá em deslindes, podendo desempenhar com mais eficiência e eficácia seu trabalho.

Com relação às entrevistas com as assistentes sociais, é complicada uma comparação entre todos os discursos, o que se pôde concluir com base nos discursos é que existe uma contradição entre as próprias percepções sobre o conhecimento utilizado pelo Serviço Social, se é ou não próprio da profissão.

Outro ponto de destaque nas entrevistas foi a contradição no reconhecimento do trabalho das entrevistadas por parte do Magistrado. Verificou-se que quando realizado um parecer dentro dos padrões estabelecidos pela organização judiciária, ou seja, atuando dentro dos atos e fatos esperados, este será em sua maioria deferido pelo Magistrado sem muita obstrução. Contudo, quando o assistente social, atuando dentro do seu compromisso ético-político, tenta promover ou viabilizar um direito que não está definido como prioridade das atividades da seção, será possivelmente indeferido pelo Magistrado. Isto se dá pelo fato do Magistrado ainda perceber o profissional como um auxiliar subordinado e não como um subsidiador. Percebe-se este fato quando se pergunta sobre a relação profissional, onde as entrevistadas afirmaram que o juiz desconhece quais são as funções destas.

Neste sentido, percebe-se que os assistentes sociais da Seção Psicossocial da CEPEMA deparam com uma realidade contraditória, o não-conhecimento, ou melhor, o desconhecimento a respeito de suas competências, obrigações e conquistas profissionais, dentro e fora da organização judiciária. Isto se deve a diversos fatores, que vão desde sua herança histórica caritativa, perpassa pela sua não-cientificização do conhecimento, além de muitos outros 
fatores implícitos que não podem ser ignorados pelos profissionais, que devem sempre lutar e criar estratégias de ocupação nos espaços institucionais para demonstrarem o poder que sua profissão detém com seus instrumentais técnico-operativos, teórico-metodológico e éticopolítico, refletidos em seus pareceres sociais que refletem diretamente na trajetória de vida de seus usuários.

Este estudo percebeu uma carência e necessidade de se produzir mais teoria sobre a instrumentalidade do Serviço Social, principalmente no que ser refere aos instrumentos técnico-operativos escritos, tais como os Laudos, Relatórios e Pareceres Sociais, pois a profissão está carente sobre a temática e excessivamente repetitiva, necessitando de novos posicionamentos e alternativas.

Por fim, esta pesquisa tende a contribuir para uma discussão maior sobre o Parecer Social como instrumento de poder do Assistente Social, como também dar visibilidade a um tema pouco discutido e muitas vezes esquecido pelos profissionais que não percebem quanto o instrumental técnico-operativo é importante e o quanto ele pode servir de meio para demonstrar todo o aparato de conhecimento que o profissional detém e, com isto todo o poder do saber da Profissão. Espera-se, portanto, que esta pesquisa sirva de incentivo para outras pesquisas futuras sobre a temática do Parecer Social e do Poder. 


\section{REFERÊNCIAS BIBLIOGRÁFICAS}

Livros e trabalhos acadêmicos:

AGUIAR, AG. Serviço Social e filosofias: das origens a Araxá. 4a ed, São Paulo: Cortez, 1985.

AGUIAR, Roberto A. R. de. Direito, Poder e Opressão. $3^{\text {a }}$ ed. São Paulo: Editora AlfaOmega, 1990.

1995.

. O que é Justiça: Uma abordagem dialética. $4^{\mathrm{a}}$ ed. São Paulo: Editora Alfa-Omega,

CARDOSO, F. G.; SERRA, B. R. V.; MORAES, I. L.; SANTOS, R. C.. Questão Social: fenômeno vinculado à histórica luta de classes e determinante básico do Serviço Social como profissão. In: SER Social, Brasília-DF, v. 06, p. 79-94, jan./jun. 2000.

CHACUR, Alice. Construção do objeto no serviço social. São Paulo: Cortez, 1983.

CHAUI, Marilena. Convite à Filosofia. São Paulo: Editora Ática, 1998.

CHUAIRI, Sílvia H. Assistência Jurídica e Serviço Social: Reflexões interdisciplinares. In Serviço Social e Sociedade, nº 67: Temas Sócio Jurídicos. São Paulo, 2001, p. 124-144.

CONSELHO FEDERAL DE SERVIÇO SOCIAL (CFESS), O estudo social em perícias, laudos e pareceres técnicos: contribuição ao debate no judiciário, no penitenciário e na previdência social. São Paulo: Cortez, 2003.

DEMO, P. Metodologia Científica em Ciências Sociais. Atlas, São Paulo, 1985.

FALEIROS, Vicente de Paula. Metodologia e Ideologia do Trabalho Social. $8^{\mathrm{a}}$ ed. São Paulo: Cortez, 1993.

. Saber profissional poder institucional. São Paulo: Cortez, 2001.

. Estratégias em serviço social. São Paulo: Cortez, 2005.

FÁVERO, E. T. (Org.) ; JORGE, M. R. T. (Org.) ; MELAO, M. J. R. (Org.) . O Serviço Social e a Psicologia no Judiciário - construindo saberes, conquistando direitos. $1^{\mathrm{a}}$. ed. São Paulo: Cortez, 2005.

FOUCAUlT, M. Microfísica do Poder. Rio de Janeiro. Edições Graal, 1979.

GIL, A.Carlos. Métodos e Técnicas de Pesquisa Social. Editora Atlas S.A. 4 edição. São Paulo, 1995. 
GUERRA, I. A instrumentalidade no trabalho do Assistente social In: Capacitação em Serviço Social. e Política Pública. Módulo 2 Brasília: CEAD, 1999

GRINOVER, A. Pelegrini; CINTRA, A.C. de Araújo; DINAMARCO, C.Rangel: Teoria Geral do Processo. $18^{\mathrm{a}}$ ed. São Paulo: Malheiros Meditores, 2002.

IAMAMOTO, M. V; CARVAlHO, R. de. Relações Sociais e Serviço Social no Brasil. Esboço de uma interpretação histórico-metodológica. 1 ${ }^{a}$. ed. São Paulo: Cortez, CELATS, 1982.

. O Serviço Social em tempos de globalização. Revista Inscrita, Rio de Janeiro, v. 3, p. 13-18, 1998.

- Transformações societárias, alterações no mundo do trabalho e Serviço Social. In: Ser Social, Brasília-DF, v. 06, p. 45-78, jan./jun. 2000.

. O Serviço Social na Contemporaneidade: trabalho e formação profissional. $9^{\mathrm{a}}$. ed. São Paulo: Cortez, 2005.

JESUS, Damásio E. de. Direito Penal: Parte Geral - $1^{\circ}$ Volume. São Paulo: Saraiva, 2003.

JOHNSON, Allan G. Dicionário de sociologia: guia prático da linguagem sociológica. Rio de Janeiro: Jorge Zahar Ed. 1997.

KAMEYAMA, N. . Concepção de Teoria e Metodologia. CADERnOS ABESS, São Paulo, v. 3, n. 1/2, p. 99-104, 1989.

LIMA, Boris Alexis. A contribuição à metodologia do Serviço Social. Belo Horizonte, Ed. Interlivros, $1^{\mathrm{a}}$ edição, 1975.

LUNGARZO, Carlos. O que é ciência. São Paulo: Editora Brasiliense, 1985.

MAGALHÃES, Selma Marques. Avaliação e Linguagem: relatórios, laudos e pareceres. São Paulo: Veras Editora- CPIHTS, 2003.

MARTINELLI, M. L. Serviço Social: Identidade e Alienação. São Paulo: Cortez, 1989.

MINAYO, M.C de S. Pesquisa Social: Teoria, método e criatividade. Rio de Janeiro: Editora Vozes Ltda, 1993.

MIOTO, R. C. T. Perícia Social: proposta de um percurso operativo. Serviço Social e Sociedade, São Paulo, v. 67, p. 145-158, 2001.

MIRABETE, Júlio Fabrini. Execução penal: comentários à Lei não ${ }^{\circ .210}$, de 11 de julho de 1984. São Paulo, 11. ed. 2004.

NETTO, José Paulo. Capitalismo Monopolista e Serviço Social. Cortez Editora, 2a edição, São Paulo, 1996. 
OLIVEIRA, Vanessa de Sousa. $O$ crime nas representações dos profissionais que atuam no campo da execução penal. 2005. 118f.. Dissertação (Mestrado em Política Social) Departamento de Serviço Social, Universidade de Brasília, Brasília 2005.

PEREIRA, Potyara A. P. - A importância da pesquisa para o desenvolvimento do Serviço Social no Brasil - UnB, mimeo, 1988.

SARMENTO, Helder Bosca de M. Intrumentos e Técnicas em Serviço Social: elementos para uma rediscussão. 1994. 315f.. Dissertação (Mestrado) Programa de estudos PósGraduados em serviço social da Pontifícia Universidade Católica de São Paulo, São Paulo, 1994.

SBABO, M. M. O Serviço Social como trabalho e profissão no poder judiciário um estudo de caso na Suprema Corte do Brasil. 2005. 191f.. Dissertação (Mestrado em Política Social) Departamento de Serviço Social, Universidade de Brasília, Brasília, 2005.

SEVERINO, A. J. Subsídios para uma reflexão sobre os novos caminhos da interdisciplinaridade. In: Serviço Social e Interdisciplinaridade. org. De Sá J. L.M; Ed. Cortez, São Paulo, 1995.

SOUZA, M. F. de. As condições, determinações e particularidades do trabalho do assistente social nos órgãos do poder judiciário sediados em Brasília. 2004. 221f.. Dissertação (Mestrado em Política Social) Departamento de Serviço Social, Universidade de Brasília, Brasília, 2004.

TRINDADE, R. L. P. Desvendando as determinações sócio históricas do instrumental técnico-operativo do Serviço Social na articulação entre demandas sociais e projetos profissionais. Temporalis, Rio de Janeiro, v. 1, n. 4, p. 21-42, 2001.

VIEIRA, Balbina Ottoni. Serviço Social: processos e técnicas. $5^{\text {a }}$ ed. Rio de Janeiro: Editora Agir, 1981.

VILA NOVA, S. Introdução à sociologia, Atlas, São Paulo, 1984. 


\section{Documentos:}

BRASIL. Presidência da República. Casa Civil. Subchefia para assuntos jurídicos. Decreto-Lei $\mathrm{n}^{\mathrm{o}}$ 3.689, de 03 de outubro de 1941 - Código de Processo Penal. Disponível em: http://www.planalto.gov.br/CCIVIL/Decreto-Lei/Del3689.htm

BRASIL. Presidência da República. Casa Civil. Subchefia para assuntos jurídicos. Decreto-Lei $\mathrm{n}^{\mathrm{o}}$ 2.848, de 07 de Dezembro de 1940 - Código Penal. Disponível em: http://www.planalto.gov.br/CCIVIL/Decreto-Lei/Del2848.htm

BRASIL. Presidência da República. Casa Civil. Subchefia para assuntos jurídicos. Lei $\mathrm{n}^{\circ}$ 7.210, de 11 de Julho de 1984. Institui a lei de Execução Penal. Disponível em: http://www.planalto.gov.br/CCIVIL/LEIS-1984/L7210.htm

BRASIL. Presidência da República. Casa Civil. Subchefia para assuntos jurídicos. Lei no 7.209, de 11 de Julho de 1984. Altera dispositivos do Decreto-Lei $\mathbf{n}^{\circ} \mathbf{2 . 8 4 8}$, de 07 de dezembro de 1940 - Código Penal, e dá outras providências. Disponível em: http://www.planalto.gov.br/CCIVIL/LEIS/1980-1988/L7209.htm

BRASIL. Presidência da República. Casa Civil. Subchefia para assuntos jurídicos. Lei ${ }^{\circ}$ 8.662, de 07 de Junho de 1984. Dispõe sobre a profissão de Assistente Social e dá outras providências. Disponível em: https://www.planalto.gov.br/ccivil_03/LEIS/L8662.htm

\section{Internet:}

DOMINGUES, Ivan. Ética, ciência e tecnologia. Kriterion., Belo Horizonte, v. 45, n. 109, 2004. Disponível em: $<$ http://www.scielo.br/scielo.php?script=sci_arttext\&pid=S0100512X2004000100007\&lng=es\&nrm=iso>. Acesso em: 16 Outubro 2006.

JESUS, C. da S; ROSA, K.T; PRAZERES, G. G. S. Metodologias de atendimento à família: o fazer do assistente social. In: Acta Scientiarum. Health Sciences Maringá, v. 26, no. 1, p. 61-70, 2004. Disponível em: <http://www.ppg.uem.br/Docs/ctf/Saude/2004_1/09 22303\%20Cristiane $\% 20 \mathrm{da} \% 20$ Silva\%20de\%20Jesus_Metodologias\%20de\%20aten\%20.pdf $>$. Acesso em: 04 de novembro de 2006. 


\section{ANEXOS}

Tabela 1.

\begin{tabular}{lcc}
\hline \multicolumn{1}{c}{ Instrumento de Trabalho } & $\mathbf{N}^{\mathbf{0}}$ de vezes citados & Porcentagem \\
\hline Entrevistas & 5 & $100 \%$ \\
Relatórios & 5 & $100 \%$ \\
Visitação (domiciliar, institucional) & 4 & $80 \%$ \\
Observação & 3 & $60 \%$ \\
Bagagem teórica (conhecimento) & 2 & $40 \%$ \\
Consulta aos autos & 2 & $40 \%$ \\
Contatos por telegrama & 1 & $20 \%$ \\
Formulário de entrevistas & 1 & $20 \%$ \\
Formulários de encaminhamento & 1 & $20 \%$ \\
Ofícios & 1 & $20 \%$ \\
\hline
\end{tabular}




\section{Roteiro das entrevistas com as assistentes sociais da Psicossocial da CEPEMA}

Idade:

Ano de Formação:

Instituição de Formação:

Ano de ingresso no TJDFT:

Cursos de especialização:

Áreas Temáticas:

Há quanto tempo está na CEPEMA:

1) Para você o Serviço Social é uma ciência ou uma disciplina científica?

2) Qual a especificidade do Serviço Social no campo das "ciências" sociais (ou humanas)?

3) Você considera o Serviço Social um serviço especializado? Se sim, como se define esta especialização?

4) Qual o referencial teórico que você utiliza para explicar e compreender a realidade?

5) O que justifica na sua opinião, a utilização do trabalho do assistente social pelos magistrados na condição de subsidiador das decisões judiciais?

6) $O$ posto de trabalho exige-lhe saberes que estão além daqueles propiciados pela formação profissional? Se sim, quais?

7) O que você entende por instrumental técnico-operativo?

8) Quais são os principais instrumentos técnico-operativos utilizados pelo assistente social da CEPEMA?

9) Quais são os tipos de demanda que chegam a seção que justifica a realização de um relatório?

10) Qual o percurso metodológico que você utiliza para realizar um relatório?

11) Qual a diferença entre parecer e relatório? Quais são as demandas que justificam a realização de um parecer ou de um relatório?

12) Qual o conteúdo teórico do relatório do assistente social, e o que o diferencia (o relatório) dos profissionais de outras áreas do conhecimento?

13) Como é a relação entre Magistrado e o Serviço Social da CEPEMA? Em qual proporção se dá o acolhimento das suas sugestões propostas nos relatórios?

14) Quais são os tipos de sugestões contidas nos relatórios e como elas interferem na trajetória processual e de vida do sentenciado? 